\title{
Timing and source constraints on the relationship between mafic and felsic intrusions in the Emeishan large igneous province
}

\author{
Hong Zhong ${ }^{\mathrm{a}, *}$, Ian H. Campbell ${ }^{\mathrm{b}}$, Wei-Guang Zhu ${ }^{\mathrm{a}}$, Charlotte M. Allen ${ }^{\mathrm{b}}$, \\ Rui-Zhong $\mathrm{Hu}^{\mathrm{a}}$, Lie-Wen Xie ${ }^{\mathrm{c}}$, De-Feng $\mathrm{He}^{\mathrm{a}}$ \\ ${ }^{a}$ State Key Laboratory of Ore Deposit Geochemistry, Institute of Geochemistry, Chinese Academy of Sciences, 46 Guanshui Road, \\ Guiyang 550002, China \\ ${ }^{\mathrm{b}}$ Research School of Earth Sciences, Australian National University, Canberra, Australia \\ ${ }^{\mathrm{c}}$ Institute of Geology and Geophysics, Chinese Academy of Sciences, Beijing 100029, China
}

Received 19 July 2010; accepted in revised form 23 December 2010; available online 31 December 2010

\begin{abstract}
Several I- and A-type granite, syenite plutons and spatially associated, giant Fe-Ti-V deposit-bearing mafic-ultramafic layered intrusions occur in the Pan-Xi (Panzhihua-Xichang) area within the inner zone of the Emeishan large igneous province (ELIP). These complexes are interpreted to be related to the Emeishan mantle plume. We present LA-ICP-MS and SIMS zircon $\mathrm{U}-\mathrm{Pb}$ ages and $\mathrm{Hf}-\mathrm{Nd}$ isotopic compositions for the gabbros, syenites and granites from these complexes. The dating shows that the age of the felsic intrusive magmatism $(256.2 \pm 3.0-259.8 \pm 1.6 \mathrm{Ma})$ is indistinguishable from that of the mafic intrusive magmatism $(255.4 \pm 3.1-259.5 \pm 2.7 \mathrm{Ma})$ and represents the final phase of a continuous magmatic episode that lasted no more than $10 \mathrm{Myr}$. The upper gabbros in the mafic-ultramafic intrusions are generally more isotopically enriched (lower $\varepsilon_{\mathrm{Nd}}$ and $\varepsilon_{\mathrm{Hf}}$ ) than the middle and lower gabbros, suggesting that the upper gabbros have experienced a higher level of crustal contamination than the lower gabbros. The significantly positive $\varepsilon_{\mathrm{Hf}}(t)$ values of the A-type granites and syenites $(+4.9$ to +10.8 ) are higher than those of the upper gabbros of the associated mafic intrusion, which shows that they cannot be derived by fractional crystallization of these bodies. They are however identical to those of the mafic enclaves $(+7.0$ to +11.4 ) and middle and lower gabbros, implying that they are cogenetic. We suggest that they were generated by fractionation of large-volume, plume-related basaltic magmas that ponded deep in the crust. The deep-seated magma chamber erupted in two stages: the first near a density minimum in the basaltic fractionation trend and the second during the final stage of fractionation when the magma was a low density Fe-poor, Si-rich felsic magma. The basaltic magmas emplaced in the shallowlevel magma chambers differentiated to form mafic-ultramafic layered intrusions accompanied by a small amount of crustal assimilation through roof melting. Evolved A-type granites (synenites and syenodiorites) were produced dominantly by crystallization in the deep crustal magma chamber. In contrast, the I-type granites have negative $\varepsilon_{\mathrm{Nd}}(t)[-6.3$ to -7.5$]$ and $\varepsilon_{\mathrm{Hf}}(t)$ [ -1.3 to -6.7$]$ values, with the $\mathrm{Nd}$ model ages $\left(T_{\mathrm{DM} 2}^{\mathrm{Nd}}\right)$ of $1.63-1.67 \mathrm{Ga}$ and $\mathrm{Hf}$ model ages $\left(T_{\mathrm{DM} 2}^{\mathrm{Hf}}\right)$ of $1.56-1.58 \mathrm{Ga}$, suggesting that they were mainly derived from partial melting of Mesoproterozoic crust. In combination with previous studies, this study also shows that plume activity not only gave rise to reworking of ancient crust, but also significant growth of juvenile crust in the center of the ELIP.
\end{abstract}

(C) 2010 Elsevier Ltd. All rights reserved.

\section{INTRODUCTION}

\footnotetext{
* Corresponding author. Tel.: +86 851589 1820; fax: +86 851 5891664.

E-mail address: zhonghong@vip.gyig.ac.cn (H. Zhong).
}

The complex interaction of asthenospheric and lithospheric processes involved in the formation of large igneous provinces (LIPs) has been attributed to mantle plume upwelling. Melting of ascending plume material and heat 
from a zone of upwelling asthenosphere may make a significant contribution to continental growth and reworking (Hill et al., 1992). The Permian Emeishan large igneous province (ELIP) of southwest China is one of the best exposed LIPs and has provided an impetus for using plume impact models to explain the formation of continental flood basalt (CFB) provinces (e.g., Chung and Jahn, 1995; Xu et al., 2001, 2004; He et al., 2003; Xiao et al., 2004). It consists of voluminous continental flood basalts, a large number of ultramafic-mafic intrusions, granites and alkaline intrusions. The duration of magmatism within the ELIP, particularly the relative timing of mafic and felsic volcanism, is critical to understanding the processes of magma production and the extent of lithospheric involvement in magma genesis. It has been demonstrated that the main pulse of tholeiitic volcanism of the ELIP occurred at $\sim 260 \mathrm{Ma}$, and that its duration was short, no more than a few million years (He et al., 2007). Recent SHRIMP $\mathrm{U}-\mathrm{Pb}$ dating studies (Zhong et al., 2007, 2009; Shellnutt et al., 2008; Xu et al., 2008) have claimed that mafic volcanism was followed by a period of felsic magmatism at $\sim 251-255 \mathrm{Ma}$ in the Pan-Xi area, implying that the Emeishan-related magmatism might be not continuous, and that there was a time gap of 5-8 Ma between mafic and felsic magmatism. However, these ages have relatively large analytical errors or may be systematically biased due to standard calibrations. This conclusion is also inconsistent with the spatial relationship between the mafic and felsic magmatism and with previous geochemistry, which suggest that the felsic magmatism is part of the ELIP. This study presents new geochronology and $\mathrm{Hf}$ and $\mathrm{Nd}$ isotopic data to evaluate the relationship between the mafic and felsic magmas of the ELIP.

Magmatic activity in the Pan-Xi area is attributed to the rising Emeishan plume head (He et al., 2003). The granites and syenites are spatially associated with major layered intrusions composed of mafic and ultramafic rocks that host the giant $\mathrm{Fe}-\mathrm{Ti}-\mathrm{V}$ oxide deposits. This relationship provides an ideal opportunity to study plume-related bimodal magmatism. Are the felsic rocks the end product of fractional crystallization of plume derived mafic magmas or are they the product of crustal melting? If the felsic magmas are the product of crustal melting how was heat transferred from the plume to the continental crust? Most previous studies of the ELIP (e.g., Chung and Jahn, 1995; Song et al., 2001; Xu et al., 2001; Zhang et al., 2006) have focused on the mafic members of the ELIP (Zhong et al., 2002, 2004; Zhou et al., 2002, 2005) although there have been some complementary studies of the petrogenesis of the felsic intrusions in the Pan-Xi area (Shellnutt and Zhou, 2007, 2008; Zhong et al., 2007, 2009; Xu et al., 2008; Shellnutt et al., 2009a,b). Despite these studies, the origin of silicic magmas and syenites, and the role of the crustal component in the genesis of the felsic members of the ELIP remain unclear because the existing studies have not produced the critical data required to distinguish between the competing hypotheses for genesis of the felsic magmas.

Integrated in situ analyses of $\mathrm{U}-\mathrm{Pb}$ and $\mathrm{Hf}$ isotopes in zircon can be used to test the competing hypotheses for the felsic magmas (Kemp et al., 2005, 2006; Anderson et al., 2009). Although zircon Hf isotopic studies of several granitic plutons in the Pan-Xi area have been carried out to constrain their source composition, there are no complimentary zircon $\mathrm{Hf}$ isotope data for the associated maficultramafic layered intrusions. If the felsic magmas were derived by fractional crystallization of the mafic magmas they should have the same age and isotopic characteristics as the mafic magmas. If they were derived by melting of the continental crust the felsic magmas should have less radiogenic Hf than the associated mafic magmas, and be the same age or perhaps slightly younger, depending on the mechanism of heat transfer. Further, if the mafic and felsic magmas are the same age the conductive heat transfer distance must be short, which would suggest that the felsic magma formed by melting the crustal roof of the mafic magma chamber. If the age of the felsic intrusions is resolvably younger than that of the mafic intrusions the felsic magmas cannot have formed in direct contact with the mafic magmas and the source of the felsic magma must be spatially separated from its heat source. In this case the felsic magma may be derived by heat conducted from the top of the mantle plume through the overlying mantle into the base of the crust (Campbell and Hill, 1988). Where this is the case the time difference between mafic and felsic magmatism can be used to calculate the conductive length scale. We therefore report zircon $\mathrm{U}-\mathrm{Pb}$ ages and $\mathrm{Nd}-\mathrm{Hf}$ isotopic compositions of granitic, alkalic and basic intrusions from four representative plutonic complexes in the $\mathrm{Pan}-\mathrm{Xi}$ area. This study aims to elucidate the link between mafic and felsic magmatism and to investigate the origin of the granites and syenites, and, in particular, to assess the relative importance of mantle and crustal components in the generation of felsic magmatism in the ELIP.

\section{GEOLOGIC BACKGROUND}

The ELIP is located near the western margin of the Yangtze block, SW China (Fig. 1). The basement of the Yangtze block consists of the Paleo-Mesoproterozoic Huili Group or its equivalents, the Yanbian or Kunyang Groups, which consist of low-grade metasedimentary rocks interbedded with felsic and mafic metavolcanic rocks, and the Neoproterozoic Kangding Complex, composed of granites and metamorphic rocks. The western margin of the Yangtze block is marked by abundant Neoproterozoic igneous rocks, consisting dominantly of mid-Neoproterozoic (830 $740 \mathrm{Ma}$ ) felsic intrusive and volcanic rocks, and minor mafic/ultramafic rocks, including basaltic lava, sills, dikes and small intrusions ( $\mathrm{Li}$ et al., 2002, 2003, 2006; Zhou et al., 2006; Zhu et al., 2006). Along the Kangdian Rift are the well-developed ca. $800 \mathrm{Ma}$ Suxiong bi-modal volcanic successions ( $\mathrm{Li}$ et al., 2002). The basement is overlain by a thick sequence $(>9 \mathrm{~km})$ of Sinian $(610-850 \mathrm{Ma})$ to Permian strata composed of clastic, carbonate and metavolcanic rocks.

The Emeishan basalts are exposed over a rhombic area of $\sim 2.5 \times 10^{5} \mathrm{~km}^{2}$, with the volcanic succession ranging from several hundred meters to $5 \mathrm{~km}$ in thickness. The province consists predominantly of basaltic flows and 


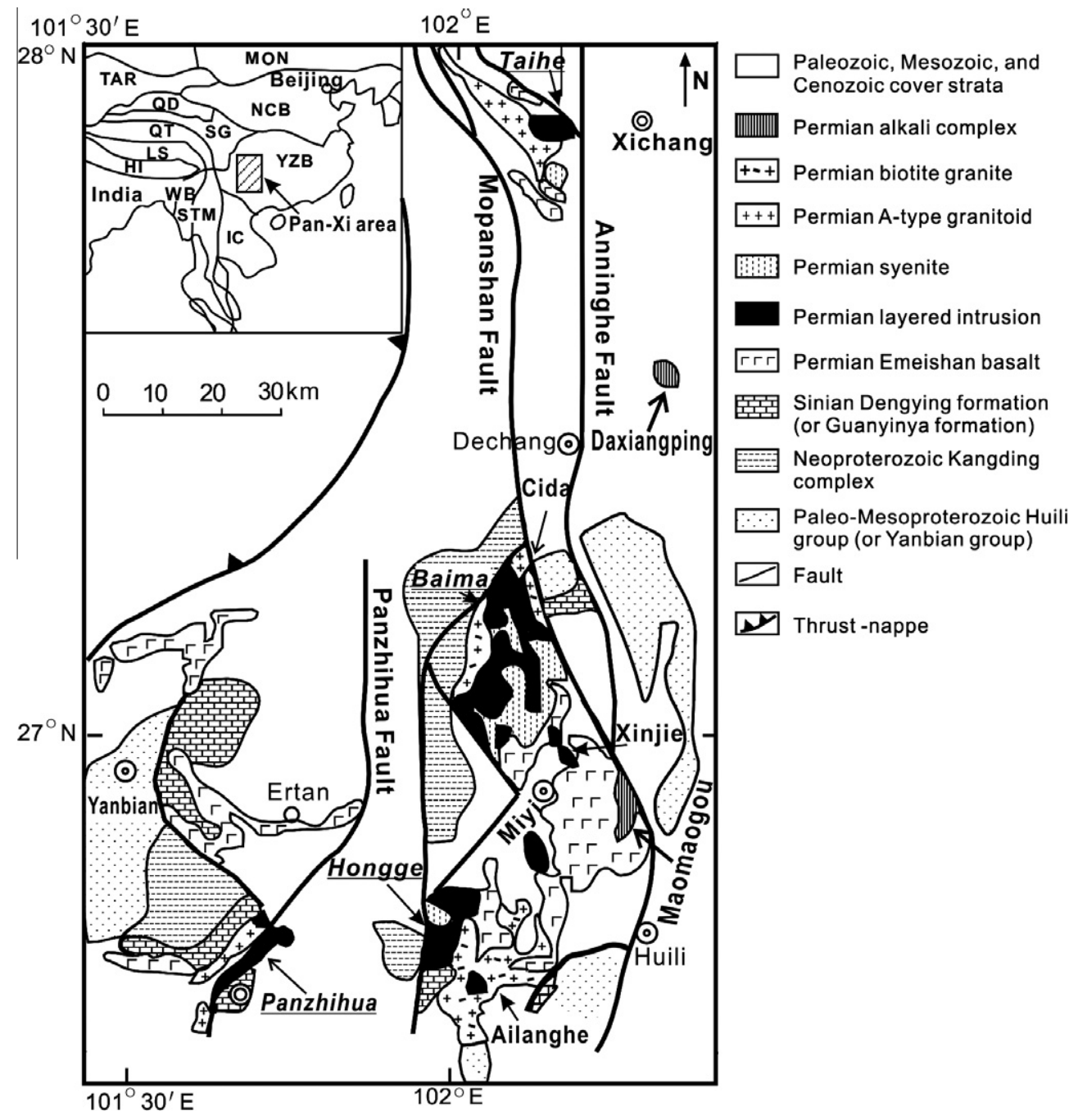

Fig. 1. Geological map of the Pan-Xi area and the distributions of the mafic/ultramafic intrusions, granites, syenites and alkaline complexes (modified after Zhong et al. (2007)). Insert illustrates distributions of major terranes in China (modified after Chung and Jahn (1995)). Abbreviations: NCB, North China block; YZB, Yangtze block; SG, Songpan-Ganze accretionary complex; QT, Qiangtang; LS, Lhasa; HI, Himalayan; TAR, Tarim; MON, Mongolia; QD, Qaidam; WB, West Burma; STM, Shan-Thai-Malay; IC, Indochina.

pyroclastics. Flows and tuffs of trachyte and rhyolite occur in the uppermost sequence of the ELIP (Chung and Jahn, 1995; Xu et al., 2001). A mantle plume is thought to be the source of the parental magma to the ELIP (Chung and Jahn, 1995; Xu et al., 2001, 2004; Song et al., 2001; He et al., 2003; Xiao et al., 2004; Zhang et al., 2006). Magnetostratigraphic data and field observations suggest that the bulk of the Emeishan volcanic sequence formed within 1-2 million years (Huang and Opdyke, 1998; Ali et al., 2002). Recent U-Pb SHRIMP dating of zircons from several coeval mafic-ultramafic intrusions, diabasic dikes and silicic ignimbrites indicate that the ELIP (Zhou et al., 2002, 2005; Guo et al., 2004; He et al., 2007; Tao et al., 2009) was voluminously erupted at $\sim 260 \mathrm{Ma}$, consistent with the end-Guadalupian stratigraphic age.

The Pan-Xi area forms part of the inner zone of the ELIP (He et al., 2003), which consists of massive flood basalts, numerous associated mafic-ultramafic intrusions and felsic intrusions. The studied intrusions are exposed along a $200 \mathrm{~km}$-long, $50 \mathrm{~km}$-wide belt bounded by $\mathrm{N}-\mathrm{S}$ trending faults. The most common felsic plutonic rocks are syenite and granite, which are spatially associated with giant $\mathrm{Fe}-$ Ti-V deposit-bearing layered mafic-ultramafic intrusions: the Panzhihua, Hongge, Baima and Taihe complexes (Fig. 1; Zhong et al., 2002, 2004, 2007; Zhou et al., 2002, 2005; Shellnutt and Zhou, 2007, 2008). Previous studies have shown that these felsic rocks represent a variety of igneous rock types that range in composition from peralkaline to metaluminous and peraluminous granites (Shellnutt and Zhou, 2007, 2008; Zhong et al., 2007, 2009; Xu et al., 2008; Shellnutt et al., 2009a,b). Field investigations reveal that these felsic intrusions always cut adjacent layered mafic-ultramafic intrusions.

\section{PETROGRAPHY AND SAMPLING}

The Panzhihua syenitic stock is spatially linked to the Panzhihua layered mafic intrusion. These granitoids intrude 
into the Emeishan basalts and the northwestern part of the Panzhihua mafic intrusion. The NE-SW striking Panzhihua gabbroic intrusion is $\sim 2 \mathrm{~km}$ thick, has an outcrop area of $\sim 30 \mathrm{~km}^{2}$ and hosts a giant $\mathrm{Fe}-\mathrm{Ti}-\mathrm{V}$ oxide deposit. This
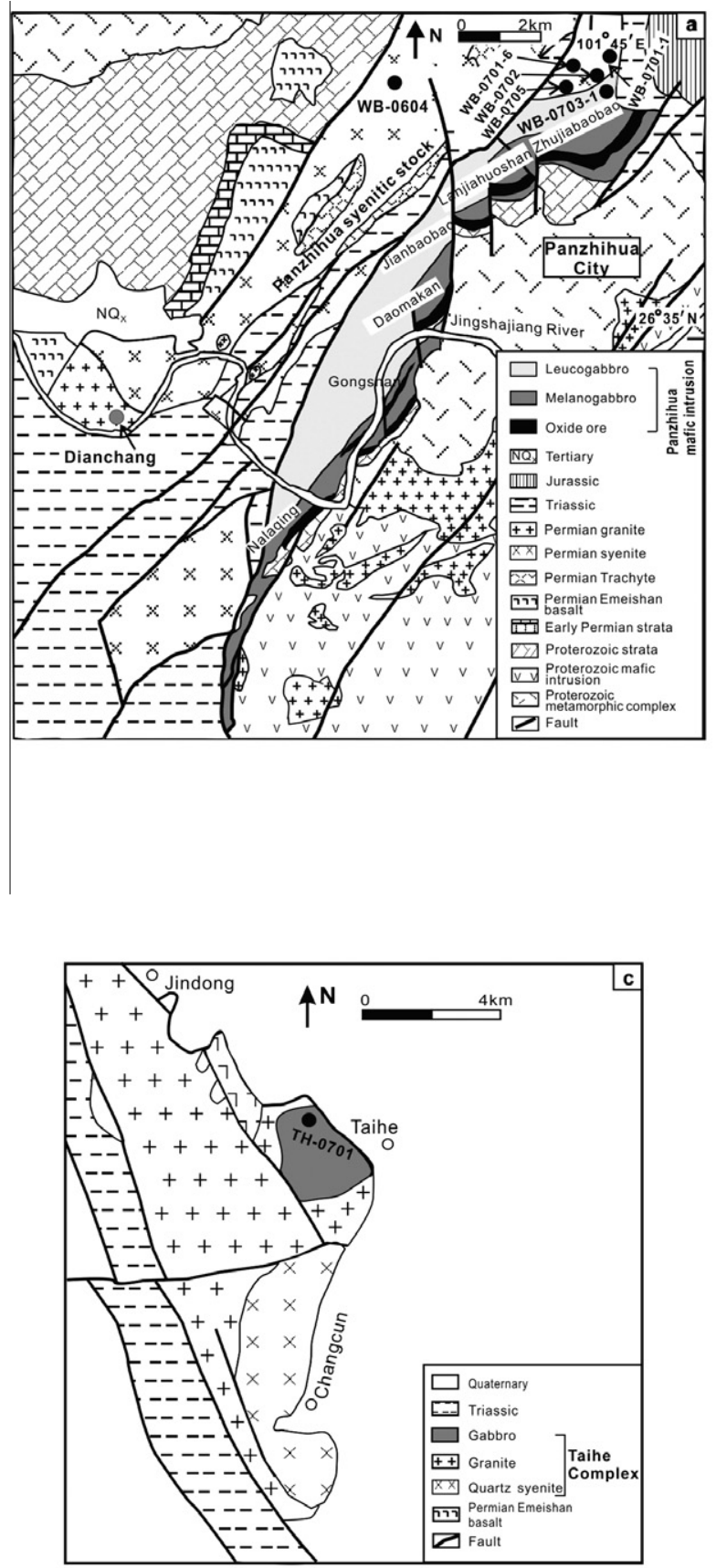

gabbroic intrusion comprises four lithologic zones from the base to top: the marginal, lower, middle and upper zones (Fig. 2a; Zhou et al., 2005). The marginal zone is $0-40 \mathrm{~m}$ thick and contains fine-grained hornblende-bearing
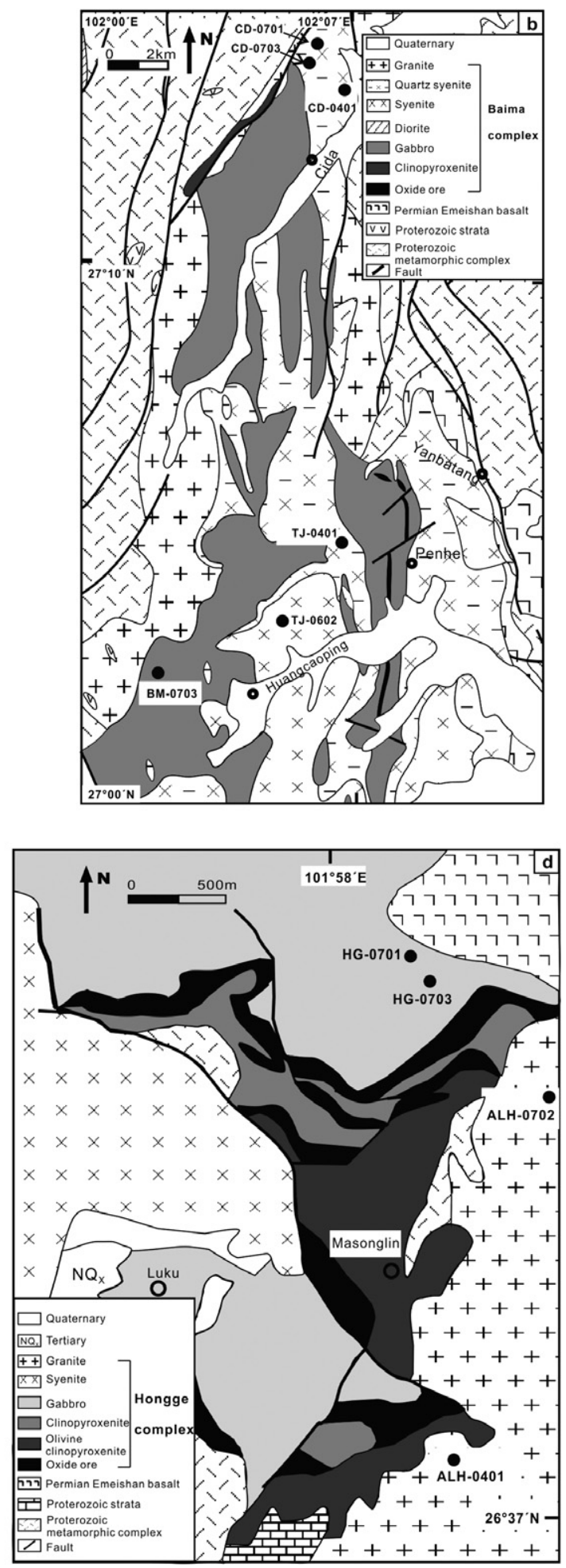

Fig. 2. Geological map of (a) the Panzhihua complex (modified after Zhou et al. (2005)); (b) the Baima complex (modified after SBGMR (1991)); (c) the Taihe complex (modified after Zhou et al. (1985)) and (d) the Hongge complex (modified after Zhong et al. (2002)). The solid circles denote age dating locations. 
gabbro and olivine gabbro with abundant marble xenoliths from the Late Neoproterozoic Dengying Formation. The lower zone ranges from 60 to $500 \mathrm{~m}$ in thickness and consists of layered melanogabbros with major $\mathrm{Fe}-\mathrm{Ti}-\mathrm{V}$ oxide layers (the main ore bodies). The middle zone, with a thickness of 170-720 m, is composed of layered melanogabbro with some oxide ore bodies. The upper zone is $500-1500 \mathrm{~m}$ thick and consists mainly of unmineralized leucogabbro (Yao et al., 1993). Most of the gabbros are medium- to coarse-grained. The melanogabbros consist of clinopyroxene $(50-60 \%)$, plagioclase $(20-30 \%)$, magnetite $(10-15 \%)$, with minor olivine $(5-10 \%)$. The leucogabbros are composed mainly of plagioclase $(60-70 \%)$, clinopyroxene $(20-25 \%)$, magnetite $(5-10 \%)$, with some apatite and hornblende (2-5\%). A small alkali gabbro (WB-0703-1) and syenodiorite (WB-0701-1, WB-0701-6, WB-0702, WB0705) occur as a sheath along the southeastern contact between the syenitic intrusion and Early Triassic sediments. The fine- to medium-grained alkali gabbros consist of approximately $50 \%$ plagioclase, $35 \%$ clinopyroxene, $10 \%$ magnetite and a few percent of apatite and hornblende, representing the uppermost part of the Panzhihua gabbroic intrusion (Shen et al., 1985). The syenodiorites are fine- to medium-grained rocks composed of mesoperthitic alkali feldspar $(50-60 \%)$, clinopyroxene $(15-20 \%)$, plagioclase $(20-25 \%)$ and magnetite $(5-8 \%)$. The spatially associated Panzhihua syenitic intrusion is about $10 \mathrm{~km} \mathrm{long}$ and $2 \mathrm{~km}$ wide. It consists mainly of syenite (WB-0604) and quartz syenite, with subordinate medium- to coarse-grained and graphic textured alkali-feldspar granite. All the main varieties of syenite and granite are leucocratic and ash-gray to pinkish-gray in color. The principal minerals are perthite, quartz, augite, aegirine-augite and/or iron-rich amphibole (Zhong et al., 2009).

The Baima syenitic intrusion is spatially associated with the Baima mafic layered intrusion (Fig. 2b). The N-S trending Baima felsic pluton intruded the chilled margins and the upper gabbro zone (BM-0703) of the Baima mafic intrusion. The chilled margins consist of fine-grained olivine gabbros, which were intruded and generally destroyed by the syenitic intrusion. The Baima mafic intrusion extends $\mathrm{N}-\mathrm{S}$ along the southern part of the Mopanshan fault. It is $24 \mathrm{~km}$ long and about $2-3 \mathrm{~km}$ wide, consisting of troctolite, plagioclase peridotite, plagioclase-bearing olivine pyroxenite, olivine gabbro and gabbro, and hosts a giant Fe-Ti-V deposit. The Baima mafic intrusion can be divided into four lithological zones: a lower mafic zone $(>100 \mathrm{~m}$ in thickness), an ultramafic zone $(\sim 70 \mathrm{~m})$, an olivine gabbro zone $(\sim 110 \mathrm{~m})$ and an upper gabbro zone $(>120 \mathrm{~m}$; Chen, 1990). The most important $\mathrm{Fe}-\mathrm{Ti}-\mathrm{V}$ oxide ore layers are hosted in the ultramafic zone, with several ore layers in the lower mafic and olivine gabbro zones. This mafic intrusion is composed predominantly of medium- to coarsegrained cumulate olivine, clinopyroxene, plagioclase and interstitial $\mathrm{Fe}-\mathrm{Ti}$ oxide minerals with minor sulfide minerals and apatite. Olivine decreases in abundance from $\sim 30 \%$ in the lower mafic and ultramafic zones to $<5 \%$ in the upper gabbro zone (Shellnutt et al., 2009b), whereas plagioclase contents generally increase upwards. The Baima felsic pluton, which includes the Huangcao, Woshui, Miyi and
Cida intrusions (Shellnutt and Zhou, 2007, 2008; Zhong et al., 2007; Xu et al., 2008), is composed of clinopyroxene syenite and amphibole-bearing syenite (TJ-0602) in the center, and quartz syenite (TJ-0401) and alkaline granite (CD0401) at the periphery. These coarse-grained felsic rocks consist of alkali feldspar (60-70\%), clinopyroxene and riebeckite $(10-15 \%)$, quartz $(5-20 \%)$, and minor apatite, plagioclase, biotite and $\mathrm{Fe}-\mathrm{Ti}$ oxides (Shellnutt and Zhou, 2007; Zhong et al., 2007). Several mafic enclaves (e.g., CD-0701 and CD-0703) occur near the margins of the Cida quartz syenitic-granitic intrusion, which are fine-grained to slightly porphyritic rocks (Fig. 2b).

The Taihe granitic pluton was emplaced in the western and southern parts of the associated Taihe layered mafic intrusion (Fig. 2c). The Taihe gabbroic intrusion (TH0701) extends ENE in a zone $4 \mathrm{~km}$ long and $3.5 \mathrm{~km}$ wide. It also contains a giant $\mathrm{Fe}-\mathrm{Ti}-\mathrm{V}$ magnetite deposit. This mafic intrusion comprises three lithologic zones: a lower olivine gabbro zone, a middle gabbro zone (hosting the major oxide ore layers) and an upper gabbro zone (Yao et al., 1993). The melanogabbros in the lower and middle zones consist mainly of clinopyroxene (45-55\%), plagioclase (15-25\%), magnetite $(10-15 \%)$ and olivine (5-15\%). The leucogabbros in the upper gabbro zone consist mostly of plagioclase $(50-65 \%)$, clinopyroxene $(20-25 \%)$, magnetite (5-10\%), with minor apatite and hornblende (3-6\%). The Taihe felsic pluton is $4-5 \mathrm{~km}$ wide, about $15 \mathrm{~km}$ long and aligned in a NNW direction along the northern part of the Anninghe fault. The pluton is composed of A-type granite, quartz syenite and amphibole-bearing syenite. The granular and coarse-grained A-type granite and quartz syenite occur in the center of the pluton, associated with the Taihe mafic intrusion (Xu et al., 2008). These granitic rocks consist predominantly of alkali feldspar (60-70\%), quartz $(20-25 \%)$ and alkali amphibole $(5-10 \%)$.

The Hongge layered mafic-ultramafic intrusion intruded the Emeishan basalts, and the dolomitic limestones of the Late Neoproterozoic Dengying Formation. The spatially associated I-type Ailanghe granitic batholith intruded the Hongge mafic-ultramafic intrusion and the adjacent Emeishan basalts (Fig. 2d). It has a fine-grained marginal zone and produced a tens to hundreds meters-wide hornfels contact zone in the adjacent gabbros and basalts (Zhong et al., 2005, 2007). The Hongge mafic-ultramafic intrusion (HG0701, HG-0703) has well-developed igneous layering and consists of three zones: a lower olivine-clinopyroxenite zone (LOZ), a middle clinopyroxenite zone (MCZ) and an upper gabbro zone (UGZ; Zhong et al., 2002). This giant $\mathrm{Fe}-\mathrm{Ti}-\mathrm{V}$ deposit-bearing intrusion occurs along the $\mathrm{N}-\mathrm{S}$ striking Xigeda fault and crops out over an area of about $60 \mathrm{~km}^{2}$. The LOZ consists predominantly of cumulate olivine $(15-30 \%)$, clinopyroxene $(40-50 \%)$ and Fe-Ti oxide (5-10\%), whereas the MCZ comprises mainly clinopyroxene $(60-70 \%)$, olivine $(5-10 \%)$ and Fe-Ti oxide (15$20 \%$ ), with minor sulfide minerals. The UGZ consists mostly of plagioclase $(40-50 \%)$, clinopyroxene $(30-40 \%)$, Fe-Ti oxide (5-10\%), with a few percent of olivine and apatite. The Ailanghe granite batholith (ALH-0401, ALH0702), which belongs to the Hongge complex, has an outcrop area of more than $100 \mathrm{~km}^{2}$. It is composed of 
coarse- to medium-grained biotite, $\mathrm{K}$-feldspar granite and medium- to fine-grained monzonitic granite (Zhong et al., 2007). The Ailanghe granite consists predominantly of $\mathrm{K}$-feldspar $(40-50 \%)$, quartz $(25-30 \%)$, plagioclase $(10-20 \%)$, minor microcline $(<5 \%)$ and biotite $(1-3 \%)$ and accessory minerals including magnetite, zircon and apatite.

\section{ANALYTICAL METHODS}

Zircons from 17 samples of gabbros, syenodiorites, syenites, granites and associated mafic enclaves from four igneous complexes in the Pan-Xi area were separated using conventional heavy liquid and magnetic techniques. Representative zircon grains were handpicked under a binocular microscope and mounted in an epoxy resin disc, and then polished and coated with gold film. Zircons were documented with transmitted and reflected light micrographs as well as cathodoluminescence (CL) images to reveal their external and internal structures. The CL images were obtained using a JEOL JXA-8900RL at the Institute of Geology in the Chinese Academy of Geological Sciences, Beijing. The zircon $\mathrm{U}-\mathrm{Pb}$ isotopic analysis for 15 samples (except HG-0701 and HG-0703) were performed using an Agilent 7500 ICP-MS equipped with a $193 \mathrm{~nm}$ Excimer laser at the Research School of Earth Sciences, Australian National University (ANU). Analytical procedures for zircon have been described in detail by Harris et al. (2004) and Campbell et al. (2006). A spot diameter of $29 \mu \mathrm{m}$ was used for all the samples, with the exception of sample WB-07031, which was dated on 22nd November of 2007 using a $54 \mu \mathrm{m}$ spot. $\mathrm{U}-\mathrm{Th}-\mathrm{Pb}$ ratios and absolute abundances were determined by reference to multiple measurements of the TEMORA zircon standard and NIST 610 glass. The R33 zircon standard (Black et al., 2004) was treated as an unknown and used for quality control (Table Annex I). The reported uncertainty for each individual $\mathrm{U}-\mathrm{Th}-\mathrm{Pb}$ zircon date is the $2 \sigma$ standard error of the observed variance in the calculated ages for each mass sweep, typically 80-90 per analysis. The uncertainty includes the calibration error from standard TEMORA, which was added in quadrature. TEMORA was also analyzed against itself on each of the analytical days and an MSWD calculated. Where the MSWD was greater than 1.0 the errors were inflated to reduced the MSWD to 1.0. We also calculate the maximum theoretical MSWD for each of the unknowns using the method of Wendt and Carl (1991). Where the observed error for the unknowns exceeds the maximum theoretical value for the unknown the errors are further inflated to bring the MSWD within the theoretical range, although this was not necessary for the unknown in the current study. The errors reported for rock ages are the $2 \sigma$ standard errors calculated from the variance in the ages for the individual zircon dates after rejecting discordant zircons and zircons that do not form part of the Gaussian population used for the date calculation. The definition of concordance is when the ${ }^{206} \mathrm{~Pb} /{ }^{238} \mathrm{U}$ age divided by the ${ }^{207} \mathrm{~Pb} /{ }^{235} \mathrm{U}$ age equals $1 \pm 0.05$ (including uncertainties). The discordant points were rejected from age calculation because they cannot be projected back to concordia with confidence (Harris et al., 2004; Campbell et al., 2006). Grains that do not form part of the Gaussian population were identified using a cumulative probability diagram as described by Campbell et al. (2006). The common- $\mathrm{Pb}$ uncorrected ages were selected in this study because they were closer to concordia than those corrected by the ${ }^{208} \mathrm{~Pb}$ method (Compston et al., 1984).

Measurements of $\mathrm{U}, \mathrm{Th}$ and $\mathrm{Pb}$ for samples HG-0701 and HG-0703 were conducted using the Cameca IMS1280 ion microprobe at the Institute of Geology and Geophysics, Chinese Academy of Sciences (IGGCAS) in Beijing. $\mathrm{U}-\mathrm{Th}-\mathrm{Pb}$ ratios and absolute abundances were determined relative to the standard zircon 91500 (Wiedenbeck et al., 1995), analyses of which were interspersed with those of unknown grains, using operating and data processing procedures similar to those described by Li et al. (2009). The mass resolution used to measure $\mathrm{Pb} / \mathrm{Pb}$ and $\mathrm{Pb} / \mathrm{U}$ isotopic ratios was 5400 during the analyses. Measured compositions were corrected for common $\mathrm{Pb}$ using nonradiogenic ${ }^{204} \mathrm{~Pb}$. Corrections are sufficiently small to be insensitive to the choice of common $\mathrm{Pb}$ composition, and an average of present-day crustal composition (Stacey and Kramers, 1975) is used for the common $\mathrm{Pb}$ assuming that the common $\mathrm{Pb}$ is largely surface contamination introduced during sample preparation.

In situ zircon $\mathrm{Hf}$ isotopic analyses were carried out using the Neptune muti-collector ICP-MS equipped with a Geolas-193 laser-ablation system (LAM-MC-ICP-MS) at the IGGCAS. During the course of this study, a laser repetition rate of $10 \mathrm{~Hz}$ at $100 \mathrm{~mJ}$ was used and beam diameters were either 32 or $63 \mu \mathrm{m}$. The isobaric interference of ${ }^{176} \mathrm{Lu}$ on ${ }^{176} \mathrm{Hf}$ was corrected by measuring the intensity of the interference-free ${ }^{175} \mathrm{Lu}$ isotope and using a recommended ${ }^{176} \mathrm{Lu} /{ }^{175} \mathrm{Lu}$ ratio of 0.02655 (Machado and Simonetti, 2001). The ${ }^{176} \mathrm{Yb} /{ }^{172} \mathrm{Yb}$ value of 0.5887 (Chu et al., 2002) and mean $\beta_{\mathrm{Yb}}$ value obtained during $\mathrm{Hf}$ analysis on the same spot were applied for the interference correction of ${ }^{176} \mathrm{Yb}$ on ${ }^{176} \mathrm{Hf}$ (Iizuka and Hirata, 2005). The detailed analytical technique and data correction procedures were described by $\mathrm{Wu}$ et al. (2006). During analyses, our routine run of the zircon standards 91500 and FM0411 gave mean ${ }^{176} \mathrm{Hf} /{ }^{177} \mathrm{Hf}$ ratios of $0.282312 \pm 41(2 \mathrm{SD}, n=38)$ and $0.282998 \pm 32(2 \mathrm{SD}, n=9)$, respectively, which are in good agreement with the reported ${ }^{176} \mathrm{Hf} /{ }^{177} \mathrm{Hf}$ ratios of $0.282306 \pm 8(2 \mathrm{SD}, n=30)$ for 91500 from solution analysis by Woodhead et al. (2004) and of $0.282983 \pm 17$ (2SD, $n=9$ ) for FM0411 from in situ analysis (Wu et al., 2006). Initial ${ }^{176} \mathrm{Hf} /{ }^{177} \mathrm{Hf}$ ratios are calculated with the reference to the chondritic reservoir (CHUR) at the time of zircon growth from the magma. A value for the decay constant of ${ }^{176} \mathrm{Lu}$ of $1.867 \times 10^{-11} \mathrm{yr}^{-1}$ (Söderlund et al., 2004) has been used in all calculations. For the calculations of $\varepsilon_{\mathrm{Hf}}$ values, we use chondritic ratios of ${ }^{176} \mathrm{Hf} /{ }^{177} \mathrm{Hf}=$ 0.282785 and ${ }^{176} \mathrm{Lu} /{ }^{177} \mathrm{Hf}=0.0336$ (Bouvier et al., 2008). These values were reported relative to ${ }^{176} \mathrm{Hf} /{ }^{177} \mathrm{Hf}=$ 0.282163 for the JMC475 standard. The model ages $\left(T^{\mathrm{Hf}}{ }_{\mathrm{DM} 2}\right)$ are calculated only for the dominantly crustal-derived I-type granites by assuming a mean ${ }^{176} \mathrm{Lu} /{ }^{177} \mathrm{Hf}$ value of 0.015 for the average continental crust (Griffin et al., 2002). 
Samples for Nd isotopic analysis were dissolved in Teflon bombs with $\mathrm{HF}+\mathrm{HNO}_{3}$ acid, and separated by conventional cation-exchange techniques. The isotopic measurements were performed on a Finnigan MAT 262 multi-collector mass spectrometer at the Laboratory for Radiogenic Isotope Geochemistry, IGGCAS. The mass fractionation corrections for $\mathrm{Nd}$ isotopic ratios are based on ${ }^{146} \mathrm{Nd} /{ }^{144} \mathrm{Nd}=0.7219$. The ${ }^{143} \mathrm{Nd} /{ }^{144} \mathrm{Nd}$ ratios of the Ames and La Jolla Nd standards determined during this study were $0.512147 \pm 10(2 \sigma)$, and $0.511852 \pm 6(2 \sigma)$, respectively.

Major elements were determined on the PANalytical Axios-advance X-ray fluorescence spectrometer (XRF) at the State Key Laboratory of Ore Deposit Geochemistry (SKLODG), Institute of Geochemistry, Chinese Academy of Sciences, using fused lithum-tetraborate glass pellets. The analytical precision is better than $5 \%$. Trace elements were analyzed using a Perkin-Elmer ELAN DRC-e ICPMS at the SKLODG. The powdered samples $(50 \mathrm{mg})$ were dissolved in high-pressure Teflon bombs using $\mathrm{HF}+\mathrm{HNO}_{3}$ mixture for $48 \mathrm{~h}$ at $\sim 190{ }^{\circ} \mathrm{C}$ (Qi et al., 2000). Rh was used as an internal standard to monitor signal drift during counting. The international standards GBPG-1, OU-6, and the Chinese National standards GSR-1 and GSR-3 were used for analytical quality control. The analytical precision is generally better than $5 \%$ for trace elements.

Major and trace element analysis are reported in Table 1. The mean age including the observed error and quoted uncertainty, and MSWD of each sample on each of the analytical days is listed in Table 2 together with the number of standard TEMORA and grains that have been used for the age calculation. U-Pb and $\mathrm{Hf}$ isotope data of zircon and whole-rock $\mathrm{Nd}$ isotopes are summarized in Table 3, and detailed $\mathrm{Nd}$ compositions of whole-rock samples are given in Table 4. U-Pb dates for the second zircon standard $\mathrm{R} 33$ are summarized in Electronic Annex I. The detailed $\mathrm{U}-\mathrm{Pb}$ and $\mathrm{Hf}$ isotope data of zircon are presented in Electronic Annex II and III.

\section{RESULTS}

\subsection{Zircon $\mathrm{U}-\mathrm{Pb}$ ages}

The two mafic enclaves hosted in the quartz syeniticgranitic intrusion from the Baima complex, are interpreted to represent the differentiated products of basaltic melts from the lower crustal magma chamber (Zhong et al., 2007), having weighted mean ${ }^{206} \mathrm{~Pb} /{ }^{238} \mathrm{U}$ ages of $259.5 \pm$ 2.7 and $259.0 \pm 3.1 \mathrm{Ma}$ (Table 2 and Fig. $3 \mathrm{a}$ and b). Zircons from the Baima gabbro (BM-0703) yield a ${ }^{206} \mathrm{~Pb} /{ }^{238} \mathrm{U}$ emplacement age of $258.2 \pm 2.2 \mathrm{Ma}$ (Table 2 and Fig. 3c). Ages of $258.5 \pm 2.3$ and $257.8 \pm 2.6 \mathrm{Ma}$ were obtained for two syenite samples from the same intrusive complex (Table 2 and Fig. $3 \mathrm{~d}$ and e). In contrast, a granite sample (CD-0401) gave an age of $256.2 \pm 1.5 \mathrm{Ma}$ (Table 2 and Fig. 3f), which is within error of the age of the other intrusions. These results are consistent with the Baima mafic enclave, gabbro, syenite and granite forming synchronously.
Zircon grains from a gabbro sample (WB-0703-1) in the Panzhihua complex, analyzed on two different days, gave ages of $257.9 \pm 2.4$ and $255.4 \pm 3.1 \mathrm{Ma}$ (Fig. $4 \mathrm{a}$ and b), which is within error of or slightly younger than a previous SHRIMP zircon U-Pb age obtained for the Panzhihua gabbro (263 $\pm 3 \mathrm{Ma}$; Zhou et al., 2005). Zircons from four samples of syenodiorite from an intrusion that form part of this complex (WB-0701-1, WB-0701-6, WB-0702 and WB-0705) have ages of $259.5 \pm 1.1 \mathrm{Ma}, 259.2 \pm 1.3 \mathrm{Ma}$, $257.8 \pm 2.3 \mathrm{Ma}$ and $259.8 \pm 1.6 \mathrm{Ma}$, which is also within error of the age for the Panzhihua gabbro (Table 2 and Fig. 4c-f). Zircon grains from syenite sample WB-0604 at Panzhihua have an age of $255.8 \pm 1.8 \mathrm{Ma}$ (Table 2 and Fig. $4 \mathrm{~g}$ ), again within error of the mafic intrusion.

Zircon grains from two samples of the Hongge complex gabbro (HG-0701 and HG-0703) gave ages of $258.7 \pm 2.0$ and $258.9 \pm 2.1 \mathrm{Ma}$, whereas two samples of I-type granite from the same complex gave ages of $256.8 \pm 2.8$ and $256.2 \pm 3.0 \mathrm{Ma}$ (Table 2 and Fig. 5a-d). One zircon grain from the I-type granites gave a disconcordant ${ }^{206} \mathrm{~Pb} /{ }^{238} \mathrm{U}$ age of $792 \mathrm{Ma}$, and is interpreted to be a xenocrystic zircon. An age of $258.8 \pm 2.3 \mathrm{Ma}$ (Table 2 and Fig. 5e) was obtained for a Taihe complex gabbro sample (TH-0701), within error of the age $(261.4 \pm 2.3 \mathrm{Ma})$ reported by $\mathrm{Xu}$ et al. (2008) for a Taihe A-type granite.

\subsection{Trace elements and $\mathrm{Hf}-\mathrm{Nd}$ isotopes}

The Baima mafic enclave and granite exhibit positive anomalies of $\mathrm{Th}, \mathrm{U}$ relative to $\mathrm{Ba}$ on a primitive mantle normalized trace element diagram and have pronounced negative $\mathrm{Nb}$, Ta anomalies, whereas the Baima gabbro and syenite show $\mathrm{Th}$, $\mathrm{U}$ depletion but no negative $\mathrm{Nb}, \mathrm{Ta}$ anomalies (Fig. 6a). All the Panzhihua gabbro, syenodiorite and syenite samples are depleted in $\mathrm{Th}$ and $\mathrm{U}$ relative to $\mathrm{Ba}$, $\mathrm{Nb}$ and $\mathrm{Ta}$ on the primitive mantle normalized multi-element profile but show no depletion of $\mathrm{Nb}$, $\mathrm{Ta}$ relative to La (Fig. 6b). The Hongge I-type granite has significant $\mathrm{Th}$ and $\mathrm{U}$ enrichment and pronounced $\mathrm{Nb}$ and $\mathrm{Ta}$ depletion, whereas $\mathrm{Nb}$ depletion in the gabbros is comparatively weak (Fig. 6c). The Taihe complex gabbro is depleted in all of the highly incompatible elements with the exception of mobile $\mathrm{Ba}$ and $\mathrm{Rb}$ (Fig. 6c).

As shown in Tables 3, 4 and Fig. 7a, the mafic enclave samples from the Baima complex have whole-rock $\varepsilon_{\mathrm{Nd}}(t)$ values of -0.7 to +0.3 , and the zircons have $\varepsilon_{\mathrm{Hf}}(t)$ values of +7.0 to +11.4 . The Baima gabbro has an $\varepsilon_{\mathrm{Nd}}(t)$ value of -1.2 , and zircon $\varepsilon_{\mathrm{Hf}}(t)$ values that range from +0.4 to +4.7 , whereas the Baima syenites have $\varepsilon_{\mathrm{Nd}}(t)$ values of +1.6 to +2.9 , and zircon $\varepsilon_{\mathrm{Hf}}(t)$ values of +5.1 to +9.8 . The granite sample from this complex has an $\varepsilon_{\mathrm{Nd}}(t)$ values of -0.6 and $\varepsilon_{\mathrm{Hf}}(t)$ values of +4.9 to +10.8 . The gabbro sample analyzed for this study (BM-0703) is from the upper gabbro zone and has a more enriched $\varepsilon_{\mathrm{Nd}}(t)$ value than those from the major cyclic units of the Baima mafic intrusion (Fig. $8 ; \varepsilon_{\mathrm{Nd}}(t)=+2.2$ to +4.6 ; Zhou et al., 2008).

The upper zone gabbro from the Panzhihua complex (WB-0703-1) has an $\varepsilon_{\mathrm{Nd}}(t)$ value of +0.9 and $\varepsilon_{\mathrm{Hf}}(t)$ values of +2.3 to +6.4 (Tables 3 and 4 , Fig. $7 b$ ). This $\varepsilon_{\mathrm{Nd}}(t)$ value is similar to those for the roof and floor rocks of the 
Table 1

Major (in wt.\%) and trace element (in ppm) data for the mafic and felsic intrusions from the Pan-Xi area.

\begin{tabular}{|c|c|c|c|c|c|c|c|c|c|c|c|c|}
\hline \multirow{3}{*}{$\begin{array}{l}\text { Sample } \\
\text { No. } \\
\text { Rock type }\end{array}$} & \multicolumn{5}{|c|}{ Baima complex } & \multicolumn{7}{|c|}{ Panzhihua complex } \\
\hline & CD-0701 & CD-0703 & BM-0703 & TJ-0602 & TJ-0401 & CD-0401 & $\begin{array}{l}\text { WB-0703- } \\
1\end{array}$ & WB-0701-1 & WB-0701-6 & WB-0702 & WB-0705 & WB-0604 \\
\hline & $\begin{array}{l}\text { Mafic } \\
\text { enclave }\end{array}$ & $\begin{array}{l}\text { Mafic } \\
\text { enclave }\end{array}$ & Gabbro & $\begin{array}{l}\text { Fayalite } \\
\text { syenite }\end{array}$ & $\begin{array}{l}\text { Quartz } \\
\text { syenite }\end{array}$ & Granite & Gabbro & $\begin{array}{l}\text { Syeno- } \\
\text { diorite }\end{array}$ & $\begin{array}{l}\text { Syeno- } \\
\text { diorite }\end{array}$ & $\begin{array}{l}\text { Syeno- } \\
\text { diorite }\end{array}$ & $\begin{array}{l}\text { Syeno- } \\
\text { diorite }\end{array}$ & Syenite \\
\hline $\mathrm{SiO}_{2}$ & 50.21 & 49.23 & 44.23 & 61.61 & 64.60 & 71.76 & 48.68 & 52.07 & 54.04 & 54.23 & 54.97 & 59.98 \\
\hline $\mathrm{TiO}_{2}$ & 1.37 & 1.21 & 3.47 & 0.78 & 0.78 & 0.42 & 2.23 & 2.31 & 2.60 & 2.14 & 2.02 & 1.28 \\
\hline $\mathrm{Al}_{2} \mathrm{O}_{3}$ & 14.52 & 15.98 & 13.92 & 16.71 & 17.47 & 12.58 & 17.44 & 13.90 & 13.88 & 12.71 & 14.94 & 13.73 \\
\hline $\mathrm{Fe}_{2} \mathrm{O}_{3}$ & 10.47 & 9.56 & 15.93 & 6.11 & 1.07 & 3.82 & 12.37 & 14.27 & 13.09 & 13.30 & 12.57 & 11.19 \\
\hline $\mathrm{MnO}$ & 0.16 & 0.14 & 0.23 & 0.25 & 0.15 & 0.05 & 0.16 & 0.34 & 0.35 & 0.33 & 0.33 & 0.40 \\
\hline $\mathrm{CaO}$ & 9.88 & 10.68 & 10.04 & 1.65 & 2.10 & 0.79 & 9.92 & 6.34 & 6.21 & 6.89 & 5.56 & 3.56 \\
\hline $\mathrm{MgO}$ & 6.66 & 7.52 & 5.42 & 0.44 & 0.63 & 0.27 & 4.79 & 2.64 & 2.93 & 3.08 & 2.19 & 0.65 \\
\hline $\mathrm{K}_{2} \mathrm{O}$ & 0.94 & 0.95 & 1.42 & 6.02 & 3.83 & 5.18 & 1.11 & 1.43 & 1.79 & 1.56 & 1.73 & 2.14 \\
\hline $\mathrm{Na}_{2} \mathrm{O}$ & 2.87 & 2.52 & 2.79 & 5.81 & 6.80 & 3.76 & 3.27 & 5.19 & 4.75 & 4.42 & 5.66 & 6.64 \\
\hline $\mathrm{P}_{2} \mathrm{O}_{5}$ & 0.28 & 0.23 & 0.67 & 0.13 & 0.12 & 0.06 & 0.29 & 0.86 & 1.04 & 1.26 & 0.68 & 0.31 \\
\hline LOI & 1.42 & 0.93 & 0.42 & 0.35 & 0.02 & 0.55 & 0.80 & 0.14 & 0.00 & 0.03 & 0.07 & 0.06 \\
\hline Total & 98.77 & 98.96 & 98.53 & 99.87 & 99.54 & 99.24 & 101.06 & 99.48 & 100.69 & 99.95 & 100.70 & 99.93 \\
\hline $\mathrm{Sc}$ & 29.6 & 25.0 & 41.9 & 9.08 & 3.29 & 3.61 & 26.2 & 13.7 & 12.9 & 14.3 & 13.4 & 14.7 \\
\hline V & 219 & 178 & 647 & 1.47 & 15.7 & 16.0 & 364 & 14.8 & 96.3 & 81.4 & 6.99 & 1.59 \\
\hline $\mathrm{Cr}$ & 119 & 154 & 28.7 & 5.15 & 3.96 & 6.23 & 114 & 26.6 & 24.6 & 31.0 & 3.39 & 4.71 \\
\hline Co & 37.4 & 28.1 & 68.7 & 1.77 & 2.15 & 2.21 & 43.6 & 11.2 & 15.1 & 14.3 & 8.87 & 2.04 \\
\hline $\mathrm{Ni}$ & 59.2 & 36.6 & 26.1 & 1.91 & 2.11 & 1.01 & 83.0 & 0.66 & - & 17.1 & 2.74 & 3.57 \\
\hline $\mathrm{Cu}$ & 60.9 & 37.3 & 47.7 & 8.09 & 2.41 & 8.47 & 150 & 11.4 & 1.61 & 14.0 & 9.24 & 6.59 \\
\hline $\mathrm{Zn}$ & 105 & 97.0 & 196 & 94.3 & 75.6 & 81.5 & 124 & 213 & 213 & 217 & 219 & 196 \\
\hline $\mathrm{Rb}$ & 33.4 & 109 & 78.9 & 52.4 & 62.4 & 94.2 & 26.0 & 20.3 & 32.9 & 23.2 & 24.2 & 35.0 \\
\hline $\mathrm{Sr}$ & 293 & 197 & 773 & 27.1 & 601 & 57 & 741 & 558 & 561 & 483 & 551 & 456 \\
\hline $\mathrm{Y}$ & 31.7 & 47.3 & 30.0 & 13.7 & 15.2 & 55.7 & 28.3 & 49.2 & 62.6 & 71.6 & 49.6 & 50.4 \\
\hline $\mathrm{Zr}$ & 107 & 211 & 84.0 & 34.6 & 246 & 1326 & 84.2 & 109 & 173 & 94.5 & 138 & 347 \\
\hline $\mathrm{Nb}$ & 19.2 & 40.1 & 37.7 & 25.2 & 33.3 & 48.0 & 17.6 & 39.3 & 114 & 73.1 & 44.6 & 58.1 \\
\hline Cs & 0.70 & 1.28 & 0.29 & 0.07 & 0.38 & 0.75 & 0.13 & 0.31 & 0.46 & 0.27 & 0.28 & 0.26 \\
\hline $\mathrm{Ba}$ & 242 & 287 & 816 & 222 & 1327 & 207 & 433 & 626 & 1008 & 729 & 813 & 1413 \\
\hline $\mathrm{Hf}$ & 3.11 & 5.15 & 2.24 & 0.87 & 5.01 & 23.7 & 2.31 & 3.72 & 4.68 & 3.29 & 4.41 & 9.40 \\
\hline $\mathrm{Ta}$ & 1.28 & 2.32 & 2.29 & 1.13 & 1.89 & 1.87 & 1.07 & 2.64 & 5.98 & 4.49 & 3.06 & 3.48 \\
\hline $\mathrm{Pb}$ & 4.02 & 7.00 & 3.59 & 4.96 & 5.95 & 8.48 & 2.12 & 4.83 & 3.30 & 5.02 & 5.60 & 6.79 \\
\hline Th & 5.66 & 15.40 & 1.83 & 0.52 & 1.48 & 33.3 & 1.75 & 3.24 & 4.56 & 3.53 & 3.67 & 5.65 \\
\hline $\mathrm{U}$ & 0.93 & 3.36 & 0.47 & 0.10 & 0.55 & 2.33 & 0.19 & 0.76 & 1.11 & 0.81 & 0.88 & 1.29 \\
\hline $\mathrm{La}$ & 27.4 & 39.6 & 31.1 & 18.3 & 44.9 & 191 & 23.1 & 47.0 & 68.9 & 72.3 & 47.2 & 54.1 \\
\hline $\mathrm{Ce}$ & 67.4 & 74.9 & 60.6 & 38.8 & 92.2 & 398 & 50.0 & 143 & 153 & 165 & 137 & 112 \\
\hline $\operatorname{Pr}$ & 6.04 & 8.42 & 7.20 & 5.44 & 12.4 & 37.7 & 6.54 & 14.5 & 20.0 & 21.0 & 14.2 & 14.9 \\
\hline $\mathrm{Nd}$ & 23.1 & 30.6 & 27.5 & 22.7 & 50.3 & 128 & 25.0 & 63.1 & 70.1 & 85.0 & 59.6 & 62.8 \\
\hline $\mathrm{Sm}$ & 4.93 & 6.49 & 5.34 & 4.42 & 7.98 & 19.7 & 6.79 & 13.1 & 17.3 & 18.8 & 13.0 & 13.8 \\
\hline
\end{tabular}


Table 1 (continued)

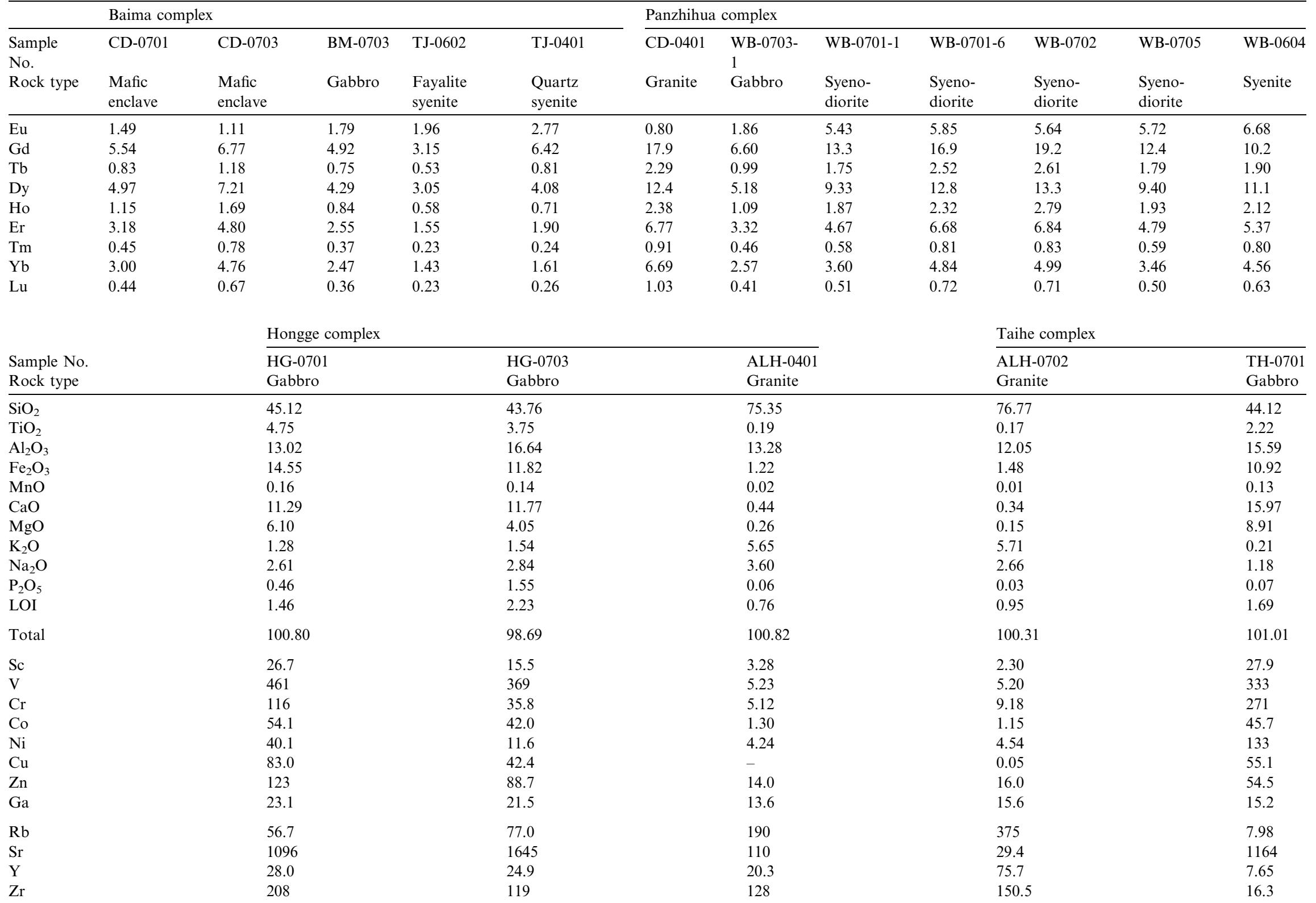




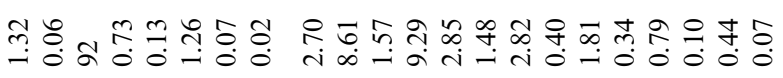

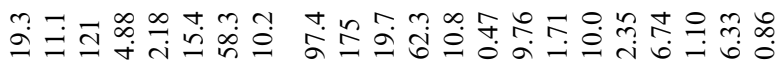

ڤิ)

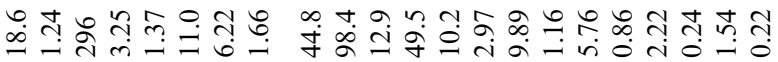

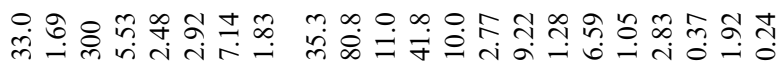

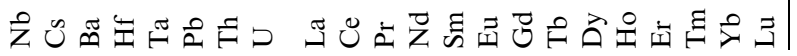

Panzhihua gabbroic intrusion $\left(\varepsilon_{\mathrm{Nd}}(t)=-2.1\right.$ to +1.1 ; Zhang et al., 2009), but is more enriched than those for the major cyclic units of this intrusion (Fig. $8 ; \varepsilon_{\mathrm{Nd}}(t)=+2.6$ to +3.2 ; Zhang et al., 2009). In contrast, the $\varepsilon_{\mathrm{Nd}}(t)$ values of the Panzhihua syenodiorites range from +2.0 to +2.6 , with $\varepsilon_{\mathrm{Hf}}(t)$ values from +5.2 to +10.4 , whereas the syenite sample has an $\varepsilon_{\mathrm{Nd}}(t)$ value of +2.7 and $\varepsilon_{\mathrm{Hf}}(t)$ values of +6.1 to +9.3 .

The gabbros from the Upper Gabbro Zone of the Hongge mafic-ultramafic intrusion gave $\varepsilon_{\mathrm{Nd}}(t)$ values of +0.1 to +0.9 and $\varepsilon_{\mathrm{Hf}}(t)$ values of +2.1 to +6.3 . These initial $\mathrm{Nd}$ isotopic compositions are similar to those for the roof and floor rocks of this intrusion $\left(\varepsilon_{\mathrm{Nd}}(t)=-2.7\right.$ to +1.0 ; Zhong et al., 2003). In contrast, the associated Ailanghe I-type granites showed significantly different $\varepsilon_{\mathrm{Nd}}(t)$ values of -6.3 to -7.5 and $\varepsilon_{\mathrm{Hf}}(t)$ values of -1.3 to -6.7 . The Corresponding the I-type granites gave $\mathrm{Nd}$ model $\left(T_{\mathrm{DM} 2}^{\mathrm{Nd}}\right)$ ages of 1627-1671 Ma and an average zircon $\mathrm{Hf}$ model ( $\left.T^{\mathrm{Hf}}{ }_{\mathrm{DM} 2}\right)$ ages of 1560-1577 Ma (Tables 3, 4 and Fig. 7c).

In the Taihe complex, the gabbro sample TH-0701 from the uppermost part of the gabbroic intrusion has an $\varepsilon_{\mathrm{Nd}}(t)$ value of +2.6 and $\varepsilon_{\mathrm{Hf}}(t)$ values that lie between +7.4 and +11.3 (Tables 3, 4 and Fig. 7d). A granite sample THG0503 from the Taihe granitic intrusion exhibits a similar $\varepsilon_{\mathrm{Nd}}(t)$ value of +2.3 (Table 4$)$. A previous study of the Taihe granite obtained $\varepsilon_{\mathrm{Hf}}(t)$ values of +7.2 to +13.5 (Xu et al., 2008).

\section{DISCUSSION}

Previous studies suggested that the parental magmas of the Fe-Ti-V oxide-bearing mafic-ultramafic layered intrusions in the Pan-Xi area were derived by melting of a mantle plume (Zhong et al., 2002; Zhou et al., 2005, 2008), resembling other global plume-related high-Ti basalts $(\mathrm{Xu}$ et al., 2001). The petrogenesis of the associated felsic intrusions has recently been discussed on the basis of their geochronological and geochemical characteristics. Zhong et al. (2007) suggested that A-type granites were formed by extensive fractional crystallization of basaltic parental magmas, whereas Shellnutt and Zhou (2007, 2008) and Shellnutt et al. (2009b) argued that the peralkaline granites are differentiation products of the layered gabbroic intrusions and that the metaluminous granites were generated by remelting of underplated cumulate material. $\mathrm{Xu}$ et al. (2008) proposed that the Salian diorites and Miyi syenites are products of fractionation from mafic rocks, and that the Taihe granites originated from gabbroic cumulates in the lower crust. In this study, detailed age and geochemical constraints are used to further elucidate the origin of the felsic intrusions and the genetic relationship between the mafic and felsic magmatism in the ELIP.

\subsection{Timing constraints on the mafic and felsic intrusions}

The geochronology summarized in Fig. 9 shows that the mafic magmatism in the intrusive complexes of the ELIP occurred between $255.4 \pm 3.1$ and $259.5 \pm 2.7 \mathrm{Ma}$, consistent with them being part of the main stage of the Emeishan magmatic activity at $259-262 \pm 3 \mathrm{Ma}$ as inferred from a 
Table 2

Summary of zircon ages for the mafic and felsic intrusions in the Pan-Xi area.

\begin{tabular}{|c|c|c|c|c|c|c|c|c|c|c|}
\hline Running day & Sample No. & Complex & Rock type & Age (Ma) & $2 \sigma$ & $\begin{array}{l}\text { Combined } \\
\text { uncertainty (Ma) }\end{array}$ & $N$ & $n$ & MSWD & Number of Temora \\
\hline 25-Jul-07 & CD-0701 & Baima & Mafic enclave & 259.5 & 2.0 & 2.7 & 20 & 20 & 1.1 & 12 \\
\hline 25-Jul-07 & CD-0703 & & Mafic enclave & 259.0 & 2.5 & 3.1 & 24 & 21 & 2.0 & 12 \\
\hline 25-Jul-07 & BM-0703 & & Gabbro & 258.2 & 1.4 & 2.2 & 25 & 25 & 0.5 & 12 \\
\hline 31-Jul-07 & TJ-0602 & & A-type fayalite syenite & 258.5 & 1.7 & 2.3 & 35 & 30 & 1.5 & 15 \\
\hline 22-Aug-07 & $\mathrm{TJ}-0401$ & & A-type quartz syenite & 257.8 & 1.7 & 2.6 & 35 & 30 & 1.0 & 13 \\
\hline 29-Aug-07 & CD-0401 & & A-type granite & 256.2 & 1.3 & 1.5 & 35 & 34 & 1.4 & 25 \\
\hline 14-Nov-07 & WB-0703-1 & Panzhihua & Gabbro & 257.9 & 2.3 & 2.4 & 35 & 30 & 0.4 & 22 \\
\hline 22-Nov-07 & WB-0703-1 & Panzhihua & Gabbro & 255.4 & 2.3 & 3.1 & 30 & 21 & 1.2 & $16^{* *}$ \\
\hline 14-Nov-07 & WB-0701-1 & & Syenodiorite & 259.5 & 0.9 & 1.1 & 35 & 31 & 0.5 & 22 \\
\hline 14-Nov-07 & WB-0701-6 & & Syenodiorite & 259.2 & 1.1 & 1.3 & 30 & 30 & 0.6 & 22 \\
\hline 25-Jul-07 & WB-0702 & & Syenodiorite & 257.8 & 1.5 & 2.3 & 20 & 20 & 0.7 & 12 \\
\hline 14-Nov-07 & WB-0705 & & Syenodiorite & 259.8 & 1.5 & 1.6 & 30 & 30 & 1.0 & 22 \\
\hline 31-Jul-07 & WB-0604 & & A-type syenite & 255.8 & 1.0 & 1.8 & 25 & 25 & 0.6 & 15 \\
\hline 23-Feb-09 & HG-0701 ${ }_{*}^{*}$ & Hongge & Gabbro & 258.7 & & 2.0 & 15 & 15 & 0.3 & $12_{*}^{*}$ \\
\hline 23-Feb-09 & HG-0703* & 1101158 & Gabbro & 258.9 & & 2.1 & 15 & 15 & 0.2 & $12^{*}$ \\
\hline 22-Aug-07 & ALH-0401 & & I-type granite & 256.8 & 1.9 & 2.8 & 35 & 26 & 1.5 & 13 \\
\hline 22-Aug-07 & ALH-0702 & & I-type granite & 256.2 & 2.2 & 3.0 & 26 & 18 & 1.3 & 13 \\
\hline 25-Jul-07 & TH-0701 & Taihe & Gabbro & 258.8 & 1.5 & 2.3 & 20 & 19 & 0.8 & 12 \\
\hline
\end{tabular}

Note. ${ }^{*}$ Samples dated by SIMS using 91500 as a standard; ${ }^{* *} \mathrm{R} 33$ used as an additional standard by applying a factor to make its U/Pb age the same as Temora and used in conjunction with 8 Temora to make a total of 16 "Temora"; $2 \sigma$ : standard error calculated from the standard deviation of the dates of the individual zircons as reported in Table Annex II. This is the error that should be used when comparing the ages of samples analyzed during the same analytical session; Combined uncertainty: total $2 \sigma$ standard error including the error from the standard, which has been added in quadrature. It is the error that should be used when comparing the ages of samples analyzed during different analytical sessions or when comparing these dates with dates from other laboratories; $N$ : number of zircons analyzed; $n$ : number used in the date calculation. The remaining grains have been rejected for the various reasons described in the text; Number of Temora: standard Temora zircons analyzed during the analytical session during which the sample was dated. The spot diameters of zircons from sample WB-0703-1 dated on 14 th November were $29 \mu \mathrm{m}$, whereas those dated on 22nd November were $54 \mu \mathrm{m}$. 
Table 3

Summary of zircon age and Nd-Hf isotopic compositions for the mafic and felsic intrusions in the Pan-Xi area.

\begin{tabular}{|c|c|c|c|c|c|c|c|c|c|c|}
\hline Sample No. & Complex & Age (Ma) & $2 \sigma(\mathrm{CU})$ & $\varepsilon_{\mathrm{Nd}}(t)$ & $2 \sigma$ & $T_{\mathrm{DM} 2}^{\mathrm{Nd}}(\mathrm{Ma})$ & $\varepsilon_{\mathrm{Hf}}(t)$ av. & $2 \sigma$ & $T_{\mathrm{DM} 2}^{\mathrm{Hf}}$ av. (Ma) & $2 \sigma$ \\
\hline CD-0701 & Baima & 259.5 & 2.7 & 0.32 & 0.25 & & 9.34 & 0.51 & & \\
\hline CD-0703 & & 259.0 & 3.1 & -0.71 & 0.27 & & 9.01 & 0.45 & & \\
\hline BM-0703 & & 258.2 & 2.2 & -1.17 & 0.23 & & 2.54 & 0.44 & & \\
\hline TJ-0602 & & 258.5 & 2.3 & 1.55 & 0.25 & & 6.39 & 0.75 & & \\
\hline TJ-0401 & & 257.8 & 2.6 & 2.93 & 0.21 & & 7.79 & 0.29 & & \\
\hline CD-0401 & & 256.2 & 1.5 & -0.61 & 0.25 & & 7.94 & 0.41 & & \\
\hline WB-0703-1 & Panzhihua & 257.9 & 2.4 & 0.93 & 0.21 & & 4.08 & 0.33 & & \\
\hline WB-0703-1 & & 255.4 & 3.1 & & & & & & & \\
\hline WB-0701-1 & & 259.5 & 1.1 & 2.01 & 0.23 & & 7.65 & 0.20 & & \\
\hline WB-0701-6 & & 259.2 & 1.3 & 2.11 & 0.25 & & 7.35 & 0.27 & & \\
\hline WB-0702 & & 257.8 & 2.3 & 2.58 & 0.23 & & 8.44 & 0.42 & & \\
\hline WB-0705 & & 259.8 & 1.6 & 2.55 & 0.23 & & 7.07 & 0.28 & & \\
\hline WB-0604 & & 255.8 & 1.8 & 2.65 & 0.21 & & 7.62 & 0.39 & & \\
\hline HG-0701 ${ }^{*}$ & Hongge & 258.7 & 2.0 & 0.90 & 0.21 & & 4.14 & 0.27 & & \\
\hline HG-0703* & & 258.9 & 2.1 & 0.06 & 0.23 & & 3.74 & 0.33 & & \\
\hline ALH-0401 & & 256.8 & 2.8 & -6.30 & 0.21 & 1627 & -4.87 & 0.37 & 1577 & 31 \\
\hline ALH-0702 & & 256.2 & 3.0 & -7.45 & 0.20 & 1671 & -4.71 & 0.35 & 1560 & 22 \\
\hline TH-0701 & Taihe & 258.8 & 2.3 & 2.57 & 0.23 & & 8.97 & 0.47 & & \\
\hline
\end{tabular}

* Samples dated by SIMS, the other samples dated by LA-ICP-MS; av, average; CU, combined uncertainty.

Table 4

$\mathrm{Nd}$ isotopic compositions for the mafic and felsic intrusions from the Pan-Xi area.

\begin{tabular}{|c|c|c|c|c|c|c|c|c|c|}
\hline Sample No. & $\mathrm{Sm}(\mathrm{ppm})$ & $\mathrm{Nd}(\mathrm{ppm})$ & ${ }^{147} \mathrm{Sm} /{ }^{144} \mathrm{Nd}$ & ${ }^{143} \mathrm{Nd} /{ }^{144} \mathrm{Nd}$ & $2 \sigma$ & $\left({ }^{143} \mathrm{Nd} /{ }^{144} \mathrm{Nd}\right)_{i}$ & $\varepsilon_{\mathrm{Nd}}(t)$ & $2 \sigma$ & $T_{\mathrm{DM} 2}^{\mathrm{Nd}}(\mathrm{Ma})$ \\
\hline CD-0701 & 5.35 & 26.03 & 0.1242 & 0.512531 & 0.000013 & 0.512320 & 0.32 & 0.25 & \\
\hline CD-0703 & 7.01 & 33.32 & 0.1272 & 0.512483 & 0.000014 & 0.512267 & -0.71 & 0.27 & \\
\hline BM-0703 & 6.31 & 33.16 & 0.1151 & 0.512439 & 0.000012 & 0.512243 & -1.17 & 0.23 & \\
\hline TJ-0602 & 4.59 & 24.05 & 0.1147 & 0.512577 & 0.000013 & 0.512383 & 1.55 & 0.25 & \\
\hline TJ-0401 & 7.98 & 50.33 & 0.0955 & 0.512616 & 0.000011 & 0.512454 & 2.93 & 0.21 & \\
\hline CD-0401 & 20.52 & 132 & 0.0936 & 0.512431 & 0.000013 & 0.512272 & -0.61 & 0.25 & \\
\hline WB-0703-1 & 6.28 & 28.25 & 0.1345 & 0.512579 & 0.000011 & 0.512351 & 0.93 & 0.21 & \\
\hline WB-0701-1 & 15.44 & 72.11 & 0.1294 & 0.512627 & 0.000012 & 0.512406 & 2.01 & 0.23 & \\
\hline WB-0701-6 & 17.54 & 83.60 & 0.1268 & 0.512627 & 0.000013 & 0.512411 & 2.11 & 0.25 & \\
\hline WB-0702 & 20.81 & 98.80 & 0.1273 & 0.512652 & 0.000012 & 0.512435 & 2.58 & 0.23 & \\
\hline WB-0705 & 14.25 & 67.07 & 0.1284 & 0.512653 & 0.000012 & 0.512434 & 2.55 & 0.23 & \\
\hline WB-0604 & 13.60 & 63.64 & 0.1286 & 0.512658 & 0.000011 & 0.512439 & 2.65 & 0.21 & \\
\hline HG-0701 & 9.38 & 44.74 & 0.1268 & 0.512565 & 0.000011 & 0.512349 & 0.90 & 0.21 & \\
\hline HG-0703 & 10.84 & 55.96 & 0.1172 & 0.512505 & 0.000012 & 0.512306 & 0.06 & 0.23 & \\
\hline ALH-0702 & 12.87 & 74.42 & 0.1045 & 0.512100 & 0.000010 & 0.511922 & -7.45 & 0.21 & 1671 \\
\hline ALH-0401 & 9.29 & 64.49 & 0.0867 & 0.512128 & 0.000011 & 0.511980 & -6.30 & 0.20 & 1627 \\
\hline ТН-0502 & 3.97 & 15.80 & 0.1510 & 0.512692 & 0.000012 & 0.512435 & 2.57 & 0.23 & \\
\hline THG-0503 & 21.67 & 119.5 & 0.1092 & 0.512606 & 0.000010 & 0.512420 & 2.28 & 0.20 & \\
\hline
\end{tabular}

Note. TH-0502 (gabbro) approximately representing sample TH-0701 in this study, THG-0503 (granite) representing sample T01 of Xu et al. (2008). All the initial isotopic ratios were corrected to $260 \mathrm{Ma}$. Two-stage $\mathrm{Nd}$ model age $\left(T_{\mathrm{DM} 2}^{\mathrm{Nd}}\right)$ is calculated using the same formulation as Keto and Jacobsen (1987).

previous study of silicic ignimbrites, the post-volcanic Xuanwei Formation and a clay tuff (He et al., 2007). The timing and duration of the felsic magmatism in the ELIP, however, is still the subject of debate. The new dating results obtained in this study for the felsic plutons, spatially associated with the mafic-ultramafic layered intrusions, indicates that they were emplaced between $256.2 \pm 3.0$ and $259.8 \pm 1.6 \mathrm{Ma}$ (Fig. 9), within error of the ages reported for the Cida granites $(261 \pm 4 \mathrm{Ma}$; Zhong et al., 2007), Woshui syenites $(260.0 \pm 2.3 \mathrm{Ma}$; Shellnutt and Zhou, 2007) and Taihe granites $(261.4 \pm 2.3 \mathrm{Ma}$; Xu et al., 2008). Our new dates show that the felsic magmatism is contemporaneous with the mafic magmatism in the
Pan-Xi area (Fig. 9), arguing against the existence of another episode of felsic magmatism between 255 and $251 \mathrm{Ma}$ (Shellnutt et al., 2008; Xu et al., 2008). Notably, the age of $256.8 \pm 2.8 \mathrm{Ma}$ reported here for the Hongge Itype granite (ALH-0401; Table 2 and Fig. 5c) is more precise than a previous age of $251 \pm 6 \mathrm{Ma}$ obtained for the same sample (Zhong et al., 2007). The new date also agrees with a date of $255.2 \pm 3.6 \mathrm{Ma}$ obtained by Xu et al. (2008) for the Hongge granites. The age of $258.5 \pm 2.3 \mathrm{Ma}$ we obtained for a Baima fayalite syenite sample (TJ-0602; Table 2, Fig. 3d), is older than the previous SHRIMP age of $252 \pm 2.5 \mathrm{Ma}$ obtained by Shellnutt and Zhou (2007) for a sample from the same intrusion. Furthermore, the age 

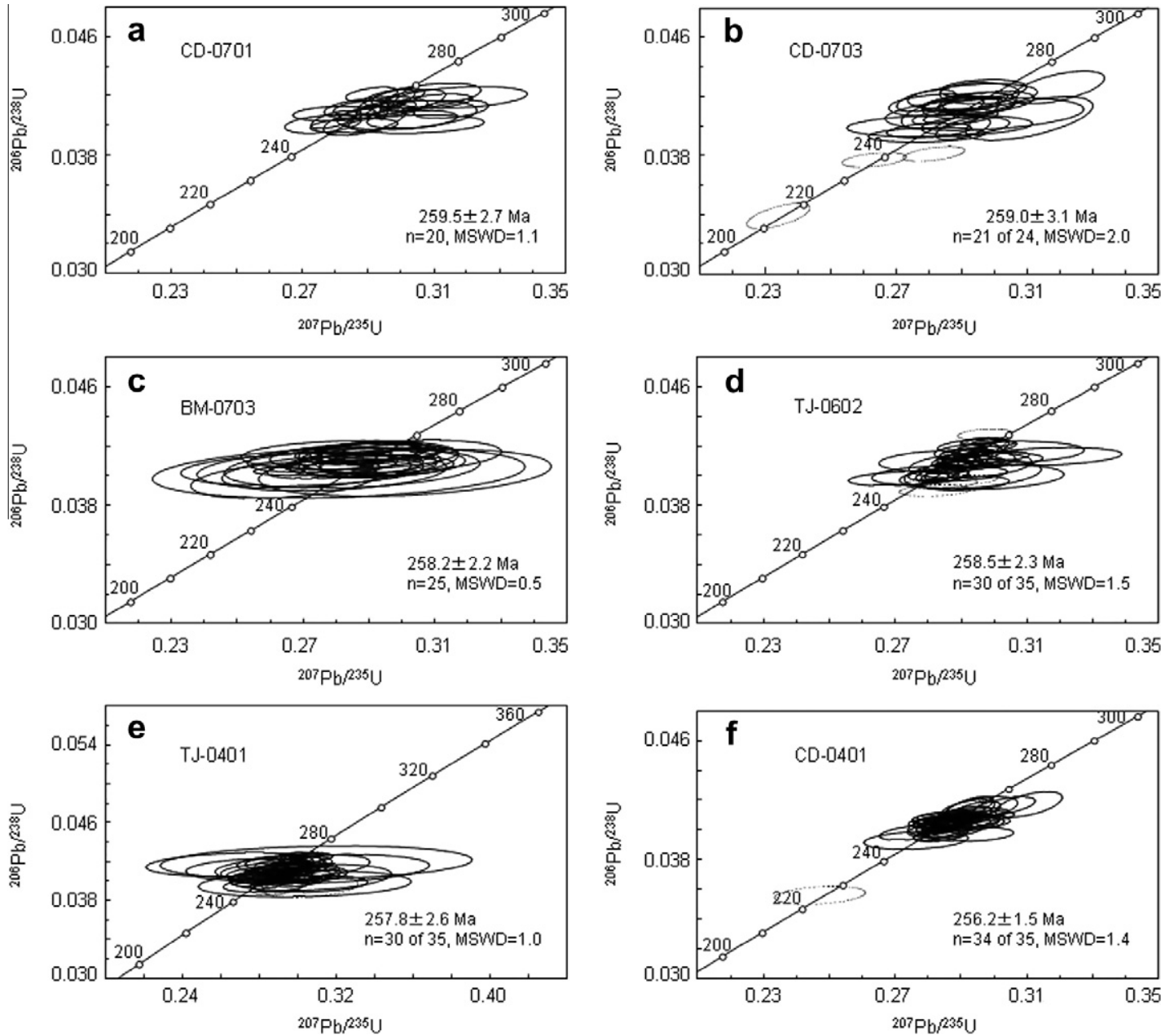

Fig. 3. LA-ICP-MS zircon U-Pb concordia diagrams for the mafic enclaves, gabbros, syenites and granites in the Baima complex. The ellipses are plotted at $2 \sigma$. The dotted ellipses were excluded from the weighted mean calculations.

of $255.8 \pm 1.8 \mathrm{Ma}$ obtained in this study (WB-0604; Table 2 and Fig. 4g) is nominally older but within error of the SHRIMP age of $253.1 \pm 1.9$ Ma reported for the same sample by Zhong et al. (2009). We checked the measurements of standard zircon TEMORA, which were used for data processing in SHRIMP U-Pb age determinations of sample WB-0604 in the previous study. The ${ }^{206} \mathrm{~Pb} /{ }^{238} \mathrm{U}$ ages of the TEMORA zircon range from 389 to $425 \mathrm{Ma}$ over the analytical period by SHRIMP (Zhong et al., 2009), with an average of $414.3 \pm 7.7 \mathrm{Ma}$ less than the previously reported value of $417 \mathrm{Ma}$ (Black et al., 2004), suggesting that the standard values for this study are slightly more precise. In contrast, the ${ }^{206} \mathrm{~Pb} /{ }^{238} \mathrm{U}$ ages of TEMORA dated by Cameca IMS-1280 ion microprobe in this study range from 404 to $424 \mathrm{Ma}$ with a mean of $415.9 \pm 2.8 \mathrm{Ma}$, which should give more precise dating results. The R33 zircon standard used in this study at ANU, which was treated as an unknown and corrected by reference to multiple measurements of TEMORA zircon in the LA-ICP-MS dating sessions (Table Annex I), gave ${ }^{206} \mathrm{~Pb} /{ }^{238} \mathrm{U}$ ages varying from 406 to $427 \mathrm{Ma}$ with a mean of $417.6 \pm 5.4 \mathrm{Ma}$ (relative to the previously reported value of 419 Ma; Black et al., 2004). Our new, more consistent data suggest that the total duration of mafic and felsic magmatism for these intrusive complexes was too short to resolve any time difference between the two phases of volcanism with the analytical techniques used in this study. The present observations are therefore contradict the previous suggestion of a distinct, later phase of felsic magmatism between 251 and $255 \mathrm{Ma}$, which followed the mafic volcanism. The total age range of the samples we dated lies only slightly outside analytical error of the mean (257.9 Ma). As shown above, the metaluminous to peralkaline A-type granites and syenites and peraluminous I-type granites (Shellnutt and Zhou, 2007, 2008; Zhong et al., 2007, 2009; Xu et al., 2008) were, within uncertainty, synchronously emplaced.

\subsection{Genetic link between mafic and felsic intrusions}

In the present study, the whole-rock $\mathrm{Nd}$ (Table 2 and Fig. 8) and average zircon Hf (Fig. 10) isotopic compositions and $\mathrm{Nb}-\mathrm{Ta}$ anomalies in the primitive mantle normalized multi-element spidergram were integrated to elucidate the role of crustal contamination in the generation of the 

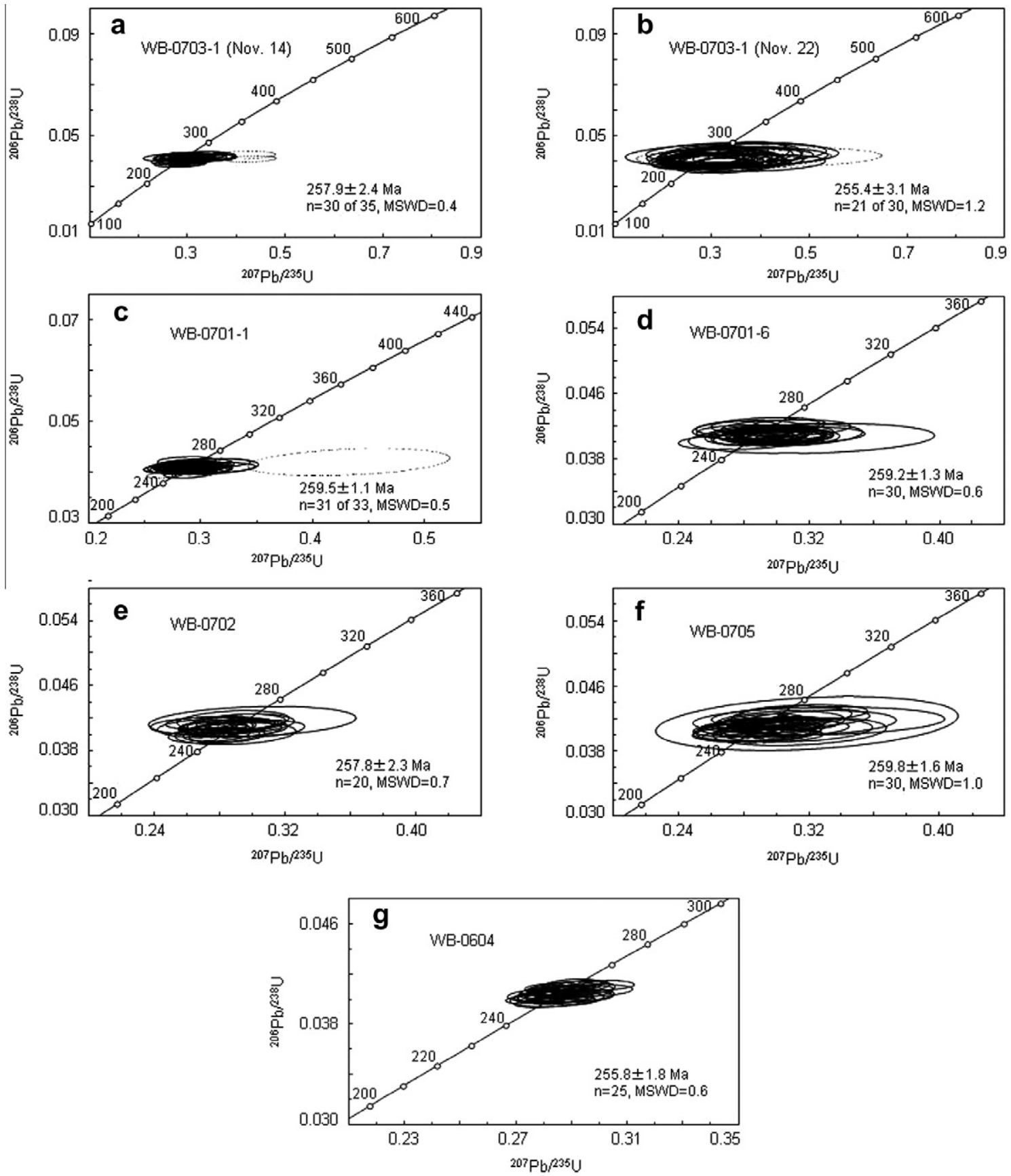

Fig. 4. LA-ICP-MS zircon U-Pb concordia diagrams for the gabbros, syenodiorites, and syenites in the Panzhihua complex. The ellipses are plotted at $2 \sigma$. The dotted ellipses were excluded from the weighted mean calculations.

mafic and felsic intrusions. As a further guide the $\mathrm{Nb} / \mathrm{U}$ ratio was also used to identify crustal contamination (Hofmann et al., 1986; Campbell, 2002). Nb/U was chosen for three reasons. First, the $\mathrm{Nb} / \mathrm{U}$ ratio of the average continental crust is 9, which compares with 48 for average MORB-type and OIB-type mantles. Furthermore the concentrations of $\mathrm{Nb}$ and $\mathrm{U}$ in the continental crust are appreciably higher than it is in the mantle. As a consequence, the $\mathrm{Nb} / \mathrm{U}$ ratio of basaltic magmas is a highly sensitive indicator of crustal contamination. Basalts with $\mathrm{Nb} / \mathrm{U}$ above the primitive mantle value of 30 (Hofmann et al., 1986) have undergone little or no crustal contamination, whereas those with values below 30 have undergone crustal contamination. Second, $\mathrm{Nb}$ and $\mathrm{U}$ have similar bulk partition coefficients during normal igneous processes so that the $\mathrm{Nb} / \mathrm{U}$ ratio is not usually affected during partial melting and fractional crystallization (but see possible exception below). Third $\mathrm{Nb} / \mathrm{U}$, unlike radiogenic isotopes such as $\mathrm{Nd}$ and $\mathrm{Hf}$, is not time dependant and so is not affected by the age difference between the basalt and the country rock. This means that $\mathrm{Nb} / \mathrm{U}$ variations can be used to identify crustal contamination where radiogenic isotopic contrast is small. 

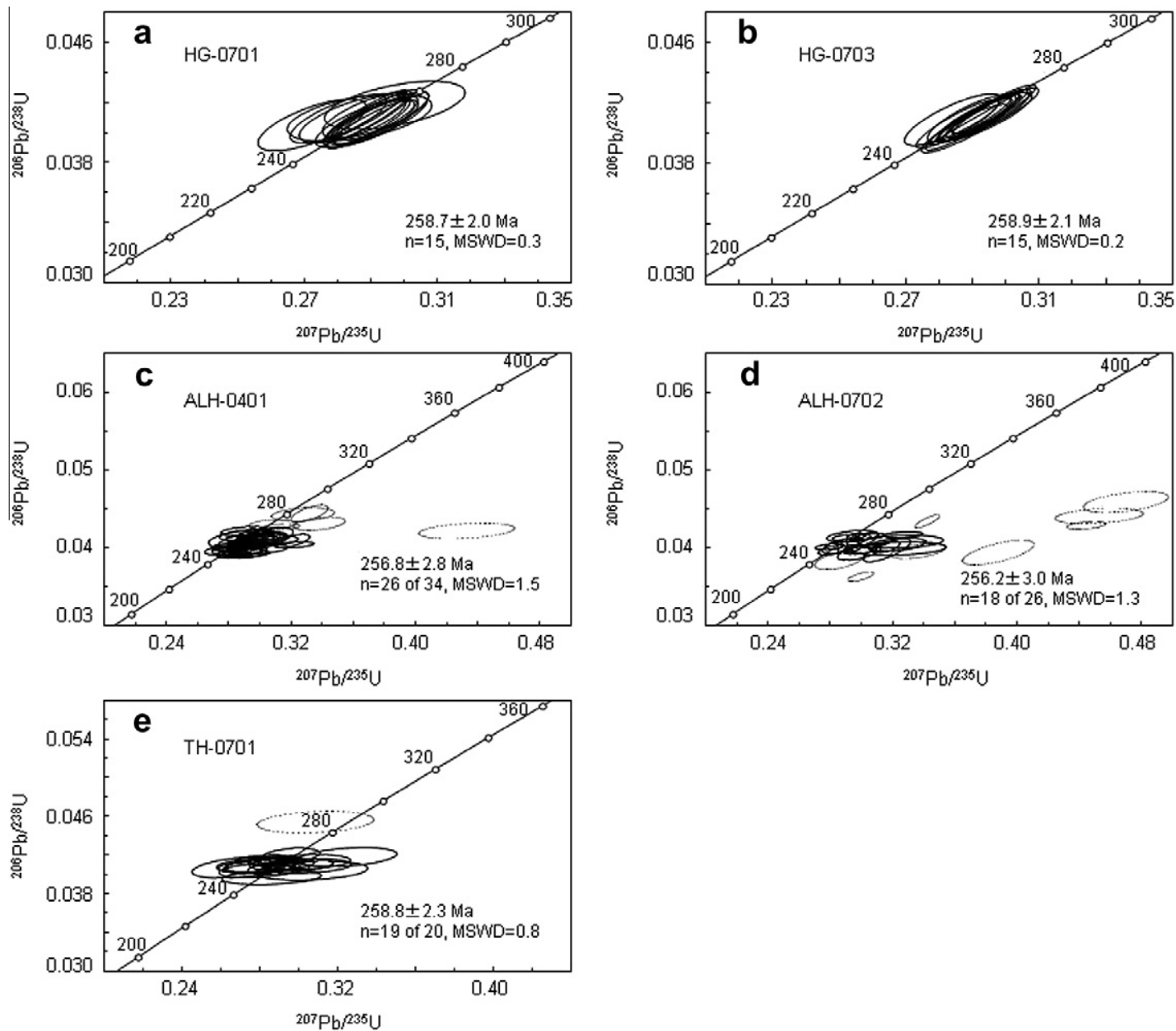

Fig. 5. SIMS (a and b) and LA-ICP-MS (c-e) zircon U-Pb concordia diagrams for the gabbros and granites in the Hongge and Taihe complexes. The ellipses are plotted at $2 \sigma$. The dotted ellipses were excluded from the weighted mean calculations.

However, it also means that no 1 to 1 correlation is expected between $\mathrm{Nb} / \mathrm{U}$ and $\mathrm{Nd}$ and $\mathrm{Hf}$ isotopes. As shown in Fig. 8, the $\mathrm{Nb} / \mathrm{U}$ ratios of the upper gabbros from the Hongge complex (11-18) are lower than the primitive mantle, and the spatially associated I-type granites are much lower again at 1.9-3.2, consistent with the obvious $\mathrm{Nb}-$ Ta depletion seen in their trace element patterns (Fig. 6c). The $\varepsilon_{\mathrm{Nd}}(t)$ values $(0.1-0.9)$ and average zircon $\varepsilon_{\mathrm{Hf}}(t)$ value $(+4.0)$ of the Hongge upper gabbros are much lower than those of the Taihe mafic intrusion $\left(\varepsilon_{\mathrm{Nd}}(t)=2.6\right.$; $\left.\varepsilon_{\mathrm{Hf}}(t)=+9.0\right)$, and the I-type granites have significantly less radiogenic $\mathrm{Nd}$ and $\mathrm{Hf}$ isotopes (Figs. 8 and 10). The above observations indicate that the Hongge upper gabbros were strongly contaminated by continental crust, whereas the Hongge granites were dominantly derived from crustal melts. In addition, the mafic enclaves and granites from the northeastern margin of the Baima complex exhibit lower $\mathrm{Nb} / \mathrm{U}$ ratios (12-21) relative to the primitive mantle. These rocks also have much lower $\varepsilon_{\mathrm{Nd}}(t)$ values than the major cyclic units of the Baima mafic intrusion (Fig. 8), again showing that they include a crustal component. However, the highly positive zircon $\varepsilon_{\mathrm{Hf}}(t)$ values of the samples (+7.9 to +9.3; Fig. 10) suggest retention of radiogenic $\mathrm{Hf}$ in igneous zircons during crustal contamination (Zheng et al., 2006), which suggests that they may have crystallized before crustal contamination. Notably, the Baima and Panzhihua upper gabbros have $\mathrm{Nb} / \mathrm{U}$ ratios within the mantle range (80-93; Fig. 8) and lack negative $\mathrm{Nb}-\mathrm{Ta}$ anomalies (Fig. 6a and b), but they exhibit less radiogenic $\mathrm{Nd}$ and $\mathrm{Hf}$ isotope ratios than the main part of the associated mafic intrusions as well as syenites and granites (Figs. 8 and 10). This may be due to ilmenite and Ti-magnetite accumulation in these gabbros (generally $>10 \%$ ). Green (1995) suggested that $\mathrm{Nb}$ and $\mathrm{Ta}$ are compatible trace elements with high $D$ values in the Ti-rich minerals, which could counteract the effect of crustal contamination in these samples. In contrast, the A-type granites and syenites (except the Baima granite sample CD-0401) have OIB-like $\mathrm{Nb} / \mathrm{U}$ ratios (45-241; Fig. 8), relatively high $\varepsilon_{\mathrm{Nd}}(t)$ values (1.6-2.9), and strongly positive zircon $\varepsilon_{\mathrm{Hf}}(t)$ values ( +6.4 to +8.4 ; Fig. 10), suggesting no significant crustal component in these felsic rocks. It has been shown that most large basaltic magma chambers melt their roofs, the Bushveld and Muskox intrusions being the best-known examples (Turner and Campbell, 1986). Thus, the studied gabbros from the upper zones of individual intrusive complexes (except the Taihe gabbro) generally 

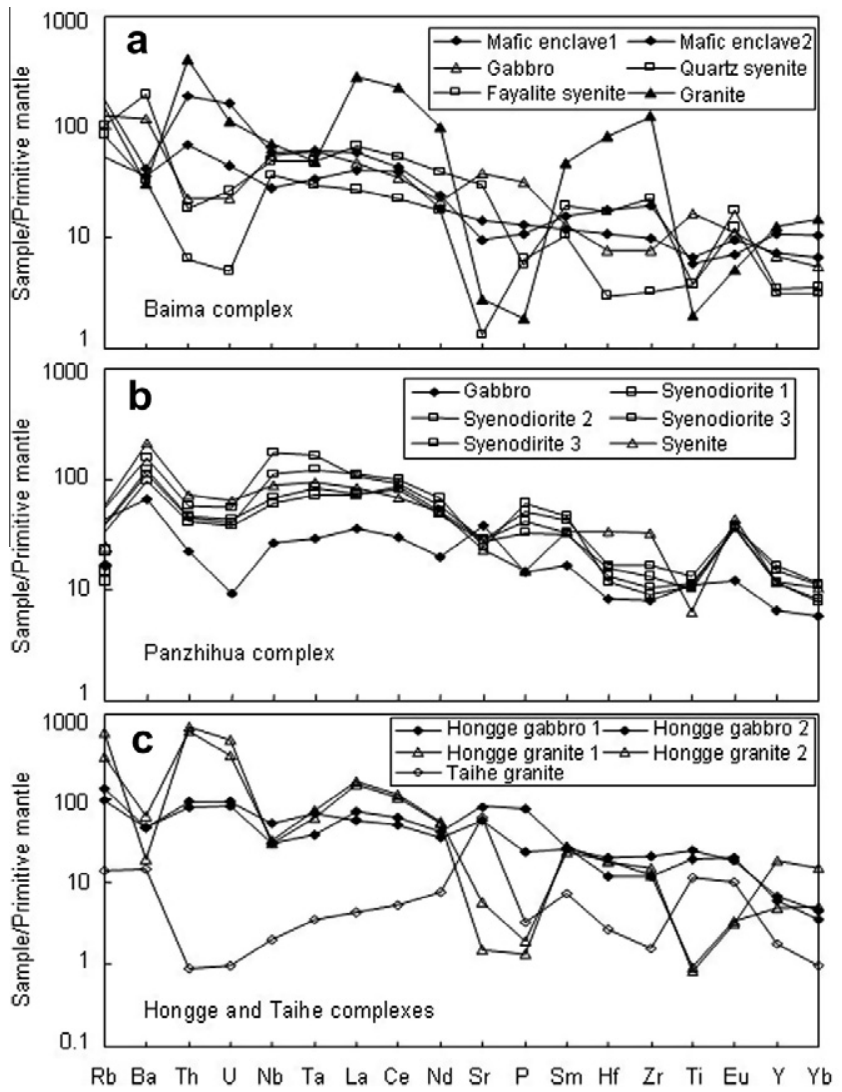

Fig. 6. Primitive mantle-normalized incompatible element distribution spidergrams for the intrusive complexes in the Pan-Xi area. The normalization values are from McDonough and Sun (1995).

have lower $\varepsilon_{\mathrm{Nd}}(t)$ and $\varepsilon_{\mathrm{Hf}}(t)$ values than those of their associated lower gabbros (Figs. 7, 8 and 10), showing that upper gabbros have experienced variable degrees of contamination by roof melting (Zhong et al., 2002; Zhou et al., 2008).

As shown above, the I-type granites from the Hongge complex have large negative $\varepsilon_{\mathrm{Nd}}(t)$ and $\varepsilon_{\mathrm{Hf}}(t)$ values, and low crustal $\mathrm{Nb} / \mathrm{U}$, which are significantly different from all other A-type granitic rocks and mafic intrusive rocks. Kemp et al. (2005) reported Hf isotope evidence and suggested that I-type magmas have higher crustal inputs. The Hongge granites have clearly formed largely or wholly by melting pre-existing continental crust. The $\mathrm{Nd}$ model ages of $1.63-1.67 \mathrm{Ga}$ and average zircon $\mathrm{Hf}$ model ages of 1.56-1.58 Ga (Tables 3 and 4) also indicate that the ancient crust has played a major role in the generation of these Itype granites. The Paleo- Mesoproterozoic Huili Group or its equivalents, the Yanbian Group, comprising lowgrade metasedimentary rocks interbedded with felsic and mafic metavolcanic rocks, occur widely in the Pan-Xi area. Conduction of heat from mafic magmas emplaced at the base of the crust could lead to partially melting the most fusible portions of the overlying Paleo-Mesoproterozoic crust. This study thus lends further support to the suggestion that the I-type granites originated largely or wholly from partial melting of a Mesoproterozoic and Paleoproterozoic crust (Shellnutt and Zhou, 2007; Zhong et al., 2007; $\mathrm{Xu}$ et al., 2008).
It has been suggested that intra-plate A-type felsic magmas may have originated by extensive fractionation of basaltic magmas (Turner et al., 1992). The present dating results indicate that the metaluminous to peralkaline Atype granites and syenites were emplaced coevally with the spatially related gabbroic rocks. The A-type granitic and syenitic rocks have similar $\mathrm{Nd}$ isotopic compositions to the major cyclic units of the associated mafic-ultramafic intrusions (Fig. 8), suggesting that their parental magmas share a common source. It is unlikely that partial melting of underplated basaltic rocks produced the large volumes of isotopically similar granitic and syenitic magmas seen in the ELIP because dry basalts are refractory and difficult to melt. The water content of a lower crustal basaltic underplate is likely to be low and it would require a large volume of high liquidus temperature, ultramafic magma to produce the observed volume of granitic and syenitic magmas. This is not impossible but highly unlikely. It is more likely that the A-type granitoids were generated by fractionation from mafic magmas. As stated above, the Panzhihua and Baima felsic rocks have $\mathrm{Nd}$ and $\mathrm{Hf}$ isotopic compositions that are similar to those of the main bodies of the associated mafic intrusions but are less radiogenic than the gabbros from the top of the intrusions (Figs. 8 and 10). This is important because it shows that syenites cannot have been formed by fractionation of the gabbros found at the same crustal level. The more evolved isotopes of the 

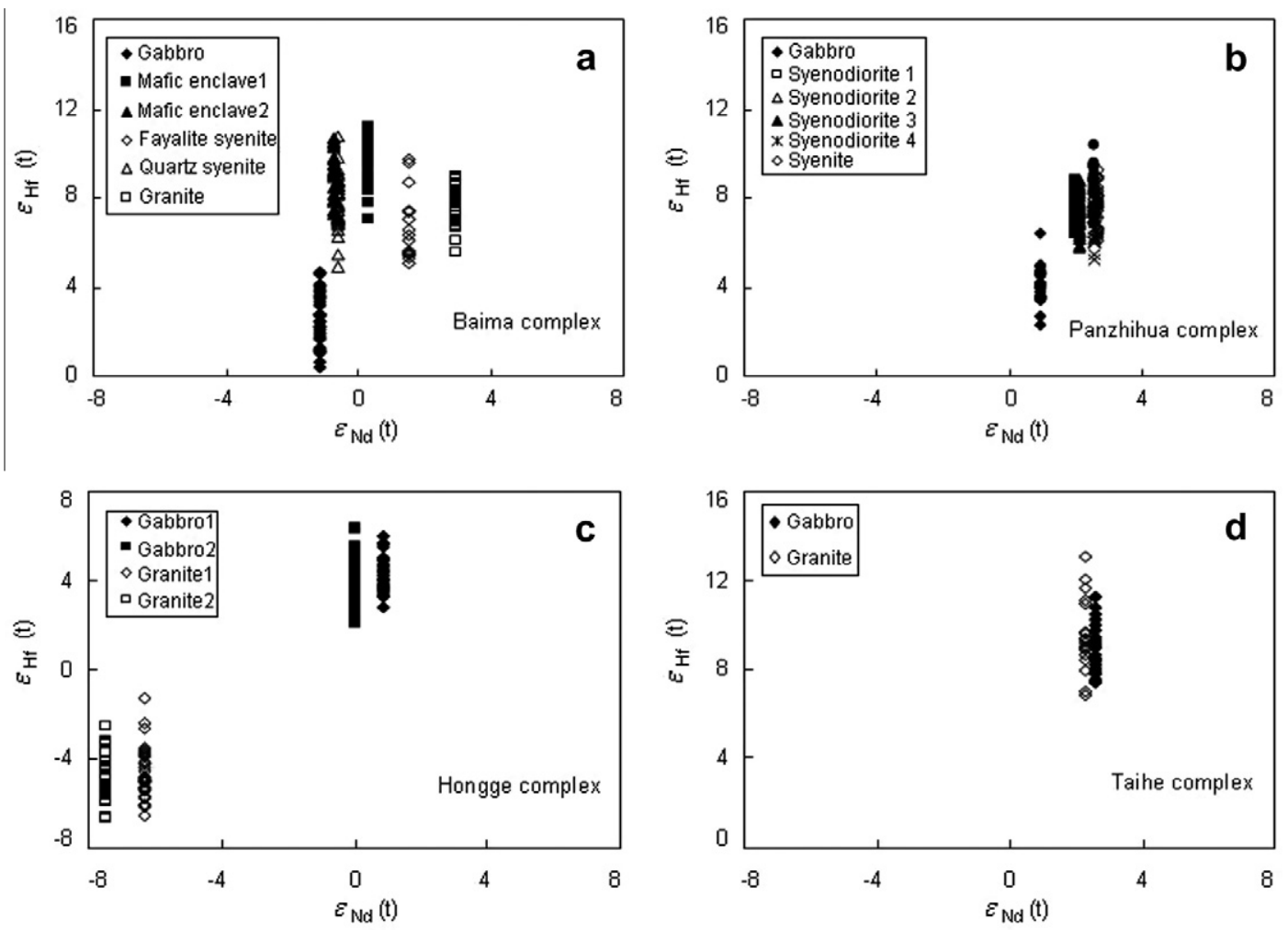

Fig. 7. The relationship between zircon $\varepsilon_{\mathrm{Hf}}(t)$ and whole-rock $\varepsilon_{\mathrm{Nd}}(t)$ values at $t=260 \mathrm{Ma}$ for the intrusive complexes in the Pan-Xi area. The Hf data for the Taihe granite from Xu et al. (2008).

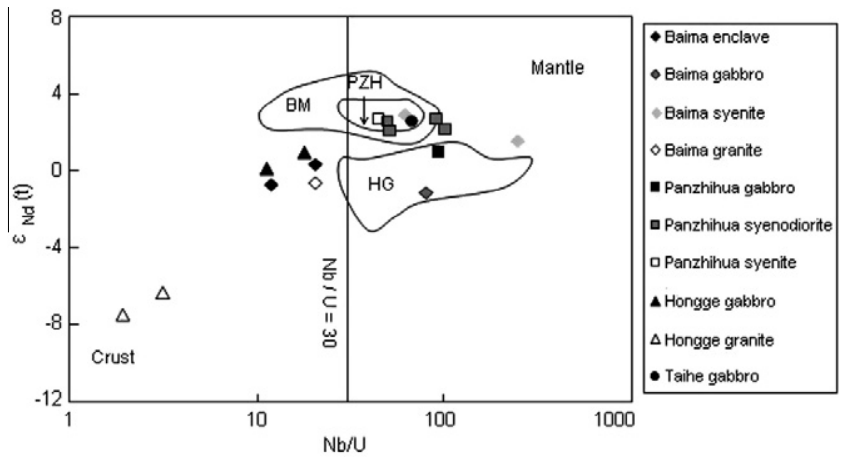

Fig. 8. Correlation of the $\mathrm{Nb} / \mathrm{U}$ versus $\varepsilon_{\mathrm{Nd}}(t)$ value for the intrusive complexes in the Pan-Xi area. BM-main part of the Baima mafic intrusion; PZH-main part of the Panzhihua mafic intrusion; HG-main part of the Hongge mafic/ultramafic intrusion. Data for BM from Zhou et al. (2008), PZH from Zhang et al. (2009) and HG from Zhong et al. (2003).

upper gabbro indicate that the upper chamber was contaminated by continental crust. If the syenites were generated by fractionation they would lie on a continuation of this trend. Their more radiogenic $\mathrm{Nd}$ and $\mathrm{Hf}$ suggest that they were not produced by fractionation of the upper level chambers. Furthermore, field mapping shows that the felsic plutons always intruded the mafic plutons. Together these observations suggest that the mafic and felsic intrusions followed different evolutionary paths from a common source, indicating that they are cogenetic but not comagmatic.

Another problem that must be considered is the volume of exposed granite and syenite is similar to (e.g., the Panzh- ihua and Baima granites) or greater (e.g., the Taihe granite) than that of the associated mafic-ultramafic layered intrusions (Fig. 1). Only small amounts of granitic magma can be generated from mafic rocks either by partial melting of the wall or roof rocks of the intrusion or by extensive fractional crystallization (Wager and Brown, 1967). The fractional crystallization model for the A-type granites and syenites in the Pan-Xi area would thus necessitate the presence of a significantly larger volume of mafic parent magma at depth than is represented by the current exposures of gabbroic rocks. Seismic wide-angle refraction studies (Zhang et al., 1988; Liu et al., 2001) indicated that a volu- 


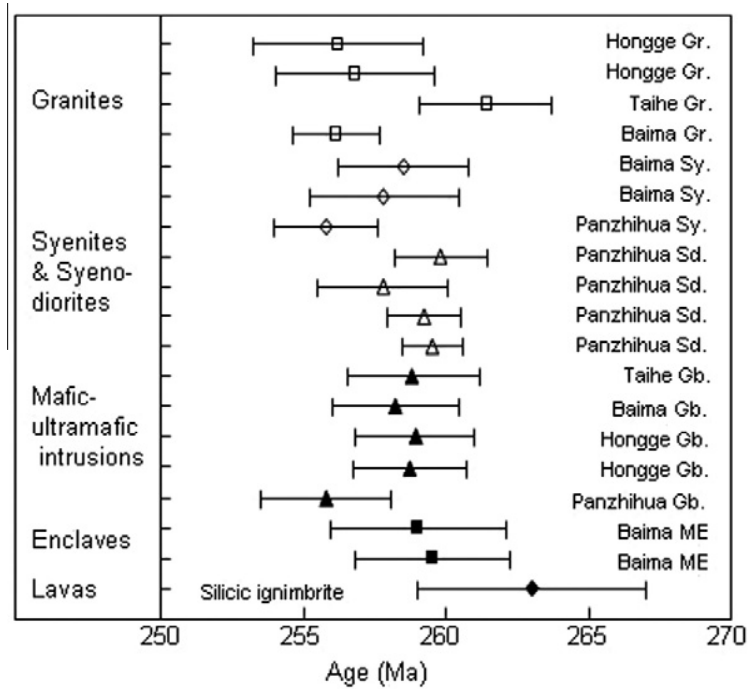

Fig. 9. Comparison of $\mathrm{U}-\mathrm{Pb}$ ages for the Panzhihua, Baima, Taihe and Hongge intrusive complexes with the age for silicic ignimbrite in the Emeishan large igneous province. Abbrevations: Gr, granite; Sy, syenite; Sd., syenodiorite; Gb, gabbro; ME-mafic enclave. The ages for the Taihe granite from $\mathrm{Xu}$ et al. (2008) and the silicic ignimbrite from $\mathrm{He}$ et al. (2007).

metrically large, high-velocity layer occurs in this region. The high-velocity seismic section is commonly referred to as "underplated igneous material". A $\sim 20 \mathrm{~km}$-thick highvelocity (7.1-7.8 km/s; Liu et al., 2001) lower crust has been identified in the Pan-Xi area, which is generally absent outside the inner zone of the ELIP (Cui et al., 1987). This type of lower crust was considered to represent the underplated material associated with the Emeishan plume upwelling $(\mathrm{Xu}$ et al., 2004). Emplacement of a widespread mafic underplate at the base of the crust in this region is also consistent with the major thermal anomaly in the lower crust, as revealed by heat flow data (Zhang et al., 1988). Ryan (1987) has suggested that the Moho is a likely place for trapping dense primitive magma due to the large density contrast between crust and mantle. The obvious location for the ponding of picritic or basaltic magma, making their way from the mantle to the Earth's surface, is the 'density trap' represented by the crust/mantle boundary beneath major flood basalt provinces (Cox, 1980; Hooper, 1988; Farnetani and Richards, 1994). This study therefore strengthens the hypothesis that the A-type granites in the ELIP were derived by differentiation of a large, mafic-ultramafic magma chamber near the base of the crust.

These mafic magmas ponded at or near the crust-mantle boundary, due to the density contrast between the crust and mantle, and gave rise to one or more large basaltic intrusions in the deep crust. The deep-seated magma chamber erupted magma in two stages: the first near the density minimum in the basaltic fractionation trend (Huppert and Sparks, 1980) and the second during the final stage of fractionation when the magma was a low density Fe-poor, Si-rich felsic magma. Evolved A-type granites (synenite and syenodiorites) were produced dominantly by crystallization of the underplated basaltic magma, whereas the coeval I-type granites were produced mainly by crustal melting.

The source of the Taihe granite, which is isotopically identical to the associated gabbro, is less clear. We cannot rule out the possibility that it fractionated from the associated upper crustal gabbro on isotopic grounds, as was the case with the Baima and Panzhihua intrusions, but because the granite is larger than the associated mafic intrusion a deep origin is more likely.

\subsection{Heat transfer and implications for growth and reworking of continental crust}

A feature of the geochronology is that the I-type granites, A-type syenites and granites and mafic-ultramafic intrusions have the same age within analytical uncertainty. However, their field relationship shows that the felsic intrusions always cut the mafic intrusions. We conclude that the felsic intrusions are younger than the mafic intrusions but that the age difference is too small to resolve by laser ICP-MS.

We have argued that the I-type Hongge granites formed largely or wholly by melting of continental crust. The small

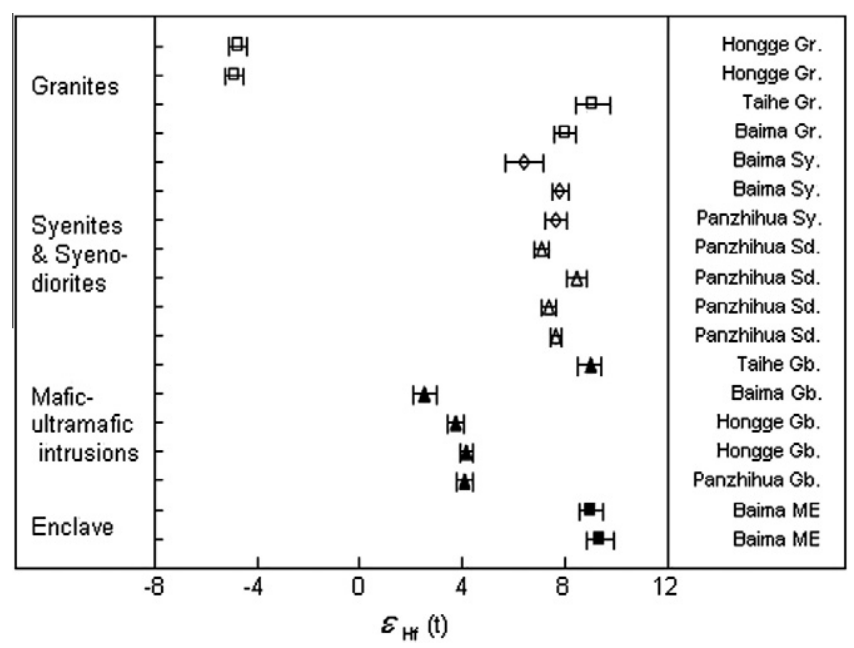

Fig. 10. Comparison of average zircon $\varepsilon_{\mathrm{Hf}}(t)$ values for the intrusive complexes in the Pan-Xi area. 
time difference between emplacement of the mafic and felsic intrusions means that the conductive distance between the heat source and zone of crustal melting must be small and this allows us to rule out conductive heat transfer from the plume as the heat source (Campbell and Hill, 1988). The life of most flood basalts is less than $1 \mathrm{Myr}$ (Campbell, 1998). The distance heat can conduct in that time is given by $X=(2 D t)^{1 / 2}$, where $X$ is distance, $t$ is time and $D$ is the diffusivity of heat, which is taken to be $10^{-6} \mathrm{~m}^{2} \mathrm{~s}^{-1}$. If we assume that the felsic intrusions formed within $1 \mathrm{Myr}$ of the gabbroic intrusions the plume must rise within $8 \mathrm{~km}$ of the base of the crust for the plume to be the heat source for crustal melting. However, because the sub-continental mantle lithosphere is cool and stiff it is difficult to displace. It is therefore unlikely that the top of the plume came to within the required $8 \mathrm{~km}$ (Campbell, 1998). The most likely source of the heat is mafic or ultramafic magma from the plume, which ponded in the lower crust, followed by conductive heat transfer and melting of the chamber roof. This hypothesis satisfies the geochronological constraint that requires a short conductive length scale for heat transfer, and is consistent with the seismic evidence for giant crustal mafic-ultramafic intrusions below the ELIP. Extensive crustal melting is also more likely to occur in the hot lower crust than in the cooler upper crustal because less heat is required to heat the crust to its melting point (Huppert and Sparks, 1988).

Field relationships show that the syenites are also consistently slightly younger than their associated mafic-ultramafic intrusions. As we have shown the geochemical evidence suggests that they were derived by fractionation of the mantle plume derived magmas. If felsic and mafic melts coexisted in the same magma chamber, the lighter felsic magma would float on the mafic magma. If the chamber was tapped, after formation of the felsic magmas, the felsic magmas would have been be drained from the chamber first, the reverse to what is observed. This means that the syenites must form in the lower crust after emplacement of the mafic magma into upper crustal magma chambers, which is expected if the syenites form by fractionation of the mafic-ultramafic magmas. It also means that the mafic-ultramafic magmas that fractionate to produce the syenites did not melt their roofs. If they had syenites would show geochemical evidence of crustal contamination, which is not observed. We therefore suggest that the mafic-ultramafic intrusions that produced the syenites intruded into continental crust that was too refractory to melt, for example previous basaltic underplate, whereas the I-type granites were produced where the host rocks were less refractory.

As shown above, the accumulation of large thickness of cumulate material in the lower crust led to extensive fractional crystallization in the large reservoirs under the central ELIP. Although caution is necessary when interpreting the $\varepsilon_{\mathrm{Hf}}(t)$ value for igneous zircons with respect to crustmantle mixing (Zheng et al., 2006), the highest $\varepsilon_{\mathrm{Hf}}(t)$ value of +10.8 for the felsic rocks, clearly indicates a significant addition of juvenile mafic material to the continental crust in the Pan-Xi area. Based on a combination of geochronological and isotopic studies, we interpret the intrusion of the granites in the Pan-Xi area to represent continental growth.

\section{CONCLUSIONS}

Geochronological and $\mathrm{Nd}-\mathrm{Hf}$ isotopic studies on the mafic-ultramafic intrusions, syenites and granites in the Pan-Xi area allow us to draw the following conclusions regarding the timing and genetic relationship between mafic and felsic magmatism in the ELIP:

(1) The age of the felsic intrusive magmatism is $256.2 \pm 3.0-259.8 \pm 1.6 \mathrm{Ma}$, which is indistinguishable from that of the mafic intrusive magmatism $(255.4 \pm 3.1-259.5 \pm 2.7 \mathrm{Ma})$ and represents the final phase of a continuous magmatic episode that lasted no more than $10 \mathrm{Myr}$.

(2) The I-type granites formed when the lower crustal mafic-ultramafic magmas intruded into fusible Paleo-Mesoproterozoic crust, which resulted in melting of the chamber roof. In contrast, the A-type granites and syenites were generated dominantly by fractionation of the basaltic magma underplated at the base of the crust where the roof was refractory and could not melt. This may happen when the magmas were injected into a previously cooled and crystallized intrusion, when successive pulses of magma entered the lower crust at similar levels. We therefore propose that the upper crustal intrusions sampled in this study were emplaced in two stages, first the mafic magmas derived from a lower crustal magma chamber, were emplaced into upper crustal chamber. This was followed by the emplacement of the felsic magmas, which differentiated from the basaltic magmas in the underplated lower crustal magma chamber.

(3) The preservation of huge volumes of juvenile underplated basalt and the felsic magmas derived from them played a crucial role in the growth and evolution of the local continental crust during the Emeishan plume activity.

\section{ACKNOWLEDGMENTS}

The authors appreciate the assistance of Dr. Caixia Feng in major element analysis by XRF, Prof. Liang Qi and Ms. Jing Hu for trace element analysis by ICP-MS, Dr. Zhuyin Chu and Mr. Chaofeng Li for Nd isotopic analysis by TIMS, Prof. Xianhua Li for zircon $\mathrm{U}-\mathrm{Pb}$ age analysis by SIMS, Prof. Fuyuan $\mathrm{Wu}$ for $\mathrm{Hf}$ isotopic analysis by LA-MC-ICP-MS. Dr. Mark Schmitz, an anonymous reviewer, and the editor Alan Brandon are thanked for their constructive reviews of this manuscript. This study was jointly supported by the National Key Basic Research Program of China (2007CB411401), the "CAS Hundred Talents" Foundation of the Chinese Academy of Sciences to H.Z., and the National Natural Science Foundation of China (40673030 and 40873028).

\section{APPENDIX A. SUPPLEMENTARY DATA}

Supplementary data associated with this article can be found, in the online version, at doi:10.1016/j.gca.2010. 12.016 . 


\section{REFERENCES}

Ali J. R., Thompson G. M., Song X. Y. and Wang Y. (2002) Emeishan basalts (SW China) and the 'end-Guadalupian' crisis: magnetobiostratigraphic constraints. J. Geol. Soc. London 159, $21-29$.

Anderson T., Anderson U. B., Graham S., Åberg G. and Simonsen S. L. (2009) Granitic magmatism by melting of juvenile crust: new constraints on the source of Palaeoproterozoic granitoids in Fennoscandia from $\mathrm{Hf}$ isotopes in zircon. J. Geol. Soc. London 166, 233-247.

Black L. P., Kamo S. L., Allen C. M., Davis D. W., Aleinikoff J. N., Valley J. W., Mundil R., Campbell I. H., Korsch R. J., Williams I. S. and Foudoulis C. (2004) Improved ${ }^{206} \mathrm{~Pb} /{ }^{238} \mathrm{U}$ microprobe geochronology by the monitoring of a traceelement-related matrix effect; SHRIMP, ID-TIMS, ELA-ICPMS and oxygen isotope documentation for a series of zircon standards. Chem. Geol. 205, 115-140.

Bouvier A., Vervoort J. D. and Patchett P. J. (2008) The Lu-Hf and $\mathrm{Sm}-\mathrm{Nd}$ isotopic composition of CHUR: constraints from unequilibrated chondrites and implications for the bulk composition of terrestrial planets. Earth Planet. Sci. Lett. 273, 4857.

Campbell I. H. (1998) The mantle's chemical structure: insights from the melting products of mantle plumes. In The Earth's Mantle: Composition, Structure and Evolution (ed. I. Jackson). Cambridge University, pp. 259-310.

Campbell I. H. (2002) Implications of $\mathrm{Nb} / \mathrm{U}, \mathrm{Th} / \mathrm{U}$ and $\mathrm{Sm} / \mathrm{Nd}$ in plume magmas for the relationship between continental and oceanic crust formation and the development of the depleted mantle. Geochim. Cosmochim. Acta 66, 1651-1661.

Campbell I. H., Ballard J. R., Palin J. M., Allen C. M. and Faunes A. (2006) U-Pb zircon geochronology of granitic rocks from the Chuquicamata-El Abra porphyry copper belt of northern Chile: Excimer laser ablation ICP-MS analysis. Econ. Geol. 101, $1327-1344$.

Campbell I. H. and Hill R. I. (1988) A two-stage model for the formation of the granite-greenstone terrains of the KalgoorlieNorseman area, Western Australia. Earth Planet. Sci. Lett. 90, $11-25$.

Chen F. W. (1990) Petrologic study on Baima ore-bearing layered mafic-ultramafic intrusion. Acta Petrol. Sin. 6(4), 12-26 (in Chinese with English abstract).

Chu N. C., Taylor R. N., Chavagnac V., Nesbitt R. W., Boella R. M., Milton J. A., Germain C. R., Bayon G. and Burton K. (2002) Hf isotope ratio analysis using multi-collector inductively coupled plasma mass spectrometry: an evaluation of isobaric interference corrections. J. Anal. At. Spectrom. 17, $1567-1574$.

Chung S. L. and Jahn B. M. (1995) Plume-lithosphere interaction in generation of the Emeishan flood basalts at the PermianTriassic boundary. Geology 23, 889-892.

Compston W., Williams I. S. and Meyer C. (1984) U-Pb geochronology of zircons from lunar breccia 73217 using sensitive high mass-resolution ion microprobe. J. Geophys. Res. 89(Suppl.), B525-B534.

Cox K. G. (1980) A model for flood basalt volcanism. J. Petrol. 21, 629-650.

Cui Z. Z., Luo D. Y., Chen J. P., Zhang Z. Y. and Huang L. Y. (1987) Deep crust structure and tectonics in the Panxi area. Acta Geophys. Sin. 30, 566-579 (in Chinese with English abstract).

Farnetani C. G. and Richards M. A. (1994) Numerical investigations of the mantle plume initiation model for flood basalt events. J. Geophys. Res. 99, 13813-13833.
Green T. H. (1995) Significance of $\mathrm{Nb} / \mathrm{Ta}$ as an indicator of geochemical processes in the crust-mantle system. Chem. Geol. 120, 347-359.

Griffin W. L., Wang X., Jackson S. E., Pearson N. J., O’Reilly S. Y., Xu X. and Zhou X. (2002) Zircon chemistry and magma mixing, SE China: in-situ analysis of Hf isotopes, Tonglu and Pingtan igneous complexes. Lithos 61, 237-269.

Guo F., Fan W. M., Wang Y. J. and Li C. W. (2004) When did the Emeishan mantle plume activity start? Geochronological and geochemical evidence from ultramafic-mafic dikes in southwestern China. Int. Geol. Rev. 46, 226-234.

Harris A. C., Allen C. M., Bryan S. E., Campbell I. H., Holcombe R. J. and Palin J. M. (2004) ELA-ICP-MS U-Pb zircon geochronology of regional volcanism hosting the Bajo de la Alumbrera $\mathrm{Cu}-\mathrm{Au}$ deposits: implications for porphyry-related mineralization. Mineral. Deposita 39, 46-67.

He B., Xu Y. G., Chung S. L., Xiao L. and Wang Y. (2003) Sedimentary evidence for a rapid crustal doming prior to the eruption of the Emeishan flood basalts. Earth Planet. Sci. Lett. 213, 389-405.

He B., Xu Y. G., Huang X. L., Luo Z. Y., Shi Y. R., Yang Q. J. and Yu S. Y. (2007) Age and duration of the Emeishan flood volcanism, SW China: geochemistry and SHRIMP zircon U-Pb dating of silicic ignimbrites, post-volcanic Xuanwei Formation and clay tuff at the Chaotian section. Earth Planet. Sci. Lett. 255, 306-323.

Hill R. I., Campbell I. H., Davies G. F. and Griffiths R. W. (1992) Mantle plumes and continental tectonics. Science 256, 186-193.

Hofmann A. W., Jochum K. P., Seufert M. and White W. M. (1986) $\mathrm{Nb}$ and $\mathrm{Pb}$ in oceanic basalts; new constraints on mantle evolution. Earth Planet. Sci. Lett. 79, 33-45.

Hooper P. R. (1988) Crystal fractionation and recharge (RFC) in the American Bar flows of the Imnaha basalt, Columbia River Basalt Group. J. Petrol. 29, 1097-1118.

Huang K. N. and Opdyke N. D. (1998) Magnetostratigraphic investigations on an Emeishan basalt section in western Guizhou province, China. Earth Planet. Sci. Lett. 163, 1-14.

Huppert H. E. and Sparks R. S. J. (1980) The fluid dynamics of a basaltic magma chamber replenished by influx of hot, dense ultrabasic magma. Contrib. Mineral. Petrol. 75, 279-289.

Huppert H. E. and Sparks R. S. J. (1988) The generation of granitic magmas by intrusion of basalt into continental crust. J. Petrol. 29, 599-624.

Iizuka T. and Hirata T. (2005) Improvements of precision and accuracy in in-situ $\mathrm{Hf}$ isotope microanalysis of zircon using the laser ablation-MC-ICPMS technique. Chem. Geol. 220, 121137.

Kemp A. I. S., Hawkesworth C. J., Paterson B. A. and Kinny P. D. (2006) Episodic growth of Gondwana supercontinent from hafnium and oxygen isotopes in zircon. Nature 439, 580-583.

Kemp A. I. S., Wormald R. J., Whitehouse M. J. and Price R. C. (2005) Hf isotopes in zircon reveal contrasting sources and crystallization histories for alkaline to peralkaline granites of Temora, southeastern Australia. Geology 33, 797-800.

Keto L. S. and Jacobsen S. B. (1987) Nd and $\mathrm{Sr}$ isotopic variations of Early Paleozoic oceans. Earth Planet. Sci. Lett. 84, 27-41.

Li X. H., Li Z. X., Sinclair J. A., Li W. X. and Carter G. (2006) Revisiting the "Yanbian Terrane": implications for Neoproterozoic tectonic evolution of the western Yangtze Block, South China. Precamb. Res. 151, 14-30.

Li X. H., Li Z. X., Zhou H., Liu Y. and Kinny P. D. (2002) U-Pb zircon geochronology, geochemistry and $\mathrm{Nd}$ isotopic study of Neoproterozoic bimodal volcanic rocks in the Kangding Rift of South China: implications for the initial rifting of Rodinia. Precamb. Res. 113, 135-154. 
Li X. H., Liu Y., Li Q. L., Guo C. H. and Chamberlain K. R. (2009) Precise determination of Phanerozoic zircon $\mathrm{Pb} / \mathrm{Pb}$ age by multi-collector SIMS without external standardization. Geochem. Geophys. Geosyst., 2009GC002400.

Li Z. X., Li X. H., Kinny P. D., Wang J., Zhang S. and Zhou H. (2003) Geochronology of Neoproterozoic syn-rift magmatism in the Yangtze Craton, South China and correlations with other continents: evidence for a mantle superplume that broke up Rodinia. Precamb. Res. 122, 85-109.

Liu J. H., Liu F. T., He J. K., Chen H. and You Q. Y. (2001) Study of seismic tomography in Panxi paleorift area of southwestern China - structural features of crust and mantle and their evolution. Sci. China (Ser. D) 44, 277-288.

Machado N. and Simonetti A. (2001) U-Pb dating and Hf isotopic composition of zircons by laser ablation-MC-ICP-MS. In Laser-Ablation-ICPMS in the Earth Sciences: Principles and Applications, vol. 29 (ed. P. Sylvester). Short Course of Mineral. Assoc., Canada, pp. 121-146.

McDonough W. F. and Sun S.-s. (1995) The composition of the Earth. Chem. Geol. 120, 223-253.

Qi L., Hu J. and Grégoire D. C. (2000) Determination of trace elements in granites by inductively coupled plasma mass spectrometry. Talanta 51, 507-513.

Ryan M. P. (1987) Neutral buoyancy and mechanical evolution of magmatic systems. Spec. Publ. Geochem. Soc. 1, 259-287.

SBGMR (Sichuan Bureau of Geology and Mineral Resources) (1991). Regional Geology of Sichuan Province. Geological Publishing House, $680 \mathrm{pp}$ (in Chinese).

Shellnutt J. G. and Zhou M. F. (2007) Permian peralkaline, peraluminous and metaluminous A-type granites in the Panxi district, SW China: their relationship to the Emeishan mantle plume. Chem. Geol. 243, 286-316.

Shellnutt J. G. and Zhou M. F. (2008) Permian, rifting related fayalite syenite in the Panxi region, SW China. Lithos 101, 54-73.

Shellnutt J. G., Wang C. Y., Zhou M. F. and Yang Y. H. (2009a) Zircon $\mathrm{Lu}-\mathrm{Hf}$ isotopic of metaluminous and peralkaline A-type granitic plutons of the Emeishan large igneous province (SW China): constraints on the mantle source. J. Asian Earth Sci. 35, $45-55$.

Shellnutt J. G., Zhou M. F. and Zellmer G. F. (2009b) The role of $\mathrm{Fe}-\mathrm{Ti}$ oxide crystallization in the formation of A-type granitoids with implications for the Daly gap: an example from the Permian Baima complex, SW China. Chem. Geol. 259, 204-217.

Shellnutt J. G., Zhou M. F., Yan D. P. and Wang Y. B. (2008) Longevity of the Permian Emeishan mantle plume (SW China): $1 \mathrm{Ma}, 8 \mathrm{Ma}$ or $18 \mathrm{Ma}$ ? Geol. Mag. 145, 373-388.

Shen F. K., Liu D., Zhang G. Z. and Wei Z. Y. (1985) An approach to the types of volcanic rock association and the genesis of bimodal magma series in Panxi paleorift. In Corpus of the Panxi Paleorift Studies in China (ed. Y. X. Zhang). Geological Publishing House, pp. 137-159 (in Chinese with English abstract).

Söderlund U., Patchett P. J., Vervoort J. D. and Isachsen C. E. (2004) The Lu-176 decay constant determined by Lu-Hf and $\mathrm{U}-\mathrm{Pb}$ isotope systematics of Precambrian mafic intrusions. Earth Planet. Sci. Lett. 219, 311-324.

Song X. Y., Zhou M. F., Hou Z. Q., Cao Z. M., Wang Y. L. and Li Y. G. (2001) Geochemical constraints on the mantle source of the upper Permian Emeishan continental flood basalts, southwestern China. Int. Geol. Rev. 43, 213-225.

Stacey J. S. and Kramers J. D. (1975) Approximation of terrestrial lead isotope evolution by a two-stage model. Earth Planet. Sci. Lett. 26, 207-221.

Tao Y., Ma Y. S., Miao L. C. and Zhu F. L. (2009) SHRIMP U$\mathrm{Pb}$ zircon age of the Jinbaoshan ultramafic intrusion, Yunnan province, SW China. Chin. Sci. Bull. 54, 168-172.
Turner J. S. and Campbell I. H. (1986) Convection and mixing in magma chambers. Earth Sci. Rev. 23, 255-352.

Turner S. P., Foden J. D. and Morrison R. S. (1992) Derivation of A-type magmas by fractionation of basaltic magma: an example from the Padthaway Ridge, South Australia. Lithos 28, 151-179.

Wager L. R. and Brown G. M. (1967) Layered Igneous Rocks. W.H. Freeman and Company, San Francisco, 588 pp.

Wendt I. and Carl C. (1991) The statistical distribution of the mean squared weighted deviation. Chem. Geol. (Isot. Geosci. Sect.) 86, 275-285.

Wiedenbeck M., Alle P., Corfu F., Griffin W. L., Meier M., Oberli F., Vonquadt A., Roddick J. C. and Speigel W. (1995) Three natural zircon standards for $\mathrm{U}-\mathrm{Th}-\mathrm{Pb}, \mathrm{Lu}-\mathrm{Hf}$, trace-element and REE analyses. Geostand. Newslett. 19, 1-23.

Woodhead J., Hergt J., Shelley M., Eggins S. and Kemp R. (2004) Zircon Hf-isotope analysis with an excimer laser, depth profiling, ablation of complex geometries, and concomitant age estimation. Chem. Geol. 209, 121-135.

Wu F. Y., Yang Y. H., Xie L. W., Yang J. H. and Xu P. (2006) Hf isotopic compositions of the standard zircons and baddeleyites used in U-Pb geochronology. Chem. Geol. 234, 105-126.

Xiao L., Xu Y. G., Mei H. J., Zheng Y. F., He B. and Pirajno F. (2004) Distinct mantle sources of low-Ti and high-Ti basalts from the western Emeishan large igneous province, SW China: implications for plume-lithosphere interaction. Earth Planet. Sci. Lett. 228, 525-546.

Xu Y. G., Chung S. L., Jahn B. M. and Wu G. Y. (2001) Petrologic and geochemical constraints on the petrogenesis of PermianTriassic Emeishan flood basalts in southwestern China. Lithos 58, 145-168.

Xu Y. G., He B., Chung S. L., Menzies M. A. and Frey F. A. (2004) Geologic, geochemical, and geophysical consequences of plume involvement in the Emeishan flood-basalt province. Geology 32, 917-920.

Xu Y. G., Luo Z. Y., Huang X. L., He B., Xiao L., Xie L. W. and Shi Y. R. (2008) Zircon U-Pb and Hf isotope constraints on crustal melting associated with the Emeishan mantle plume. Geochim. Cosmochim. Acta 72, 3084-3104.

Yao P. H., Wang K. N., Du C. L., Lin Z. T. and Song X. (1993) Records of China's Iron Ore Deposits. Metallurgic Industry Press, Beijing, pp. 633-649 (in Chinese with English abstract).

Zhang Y. X., Luo Y. N. and Yang C. X. (1988) Panxi Rift. Geological Publishing House, p. 325 (in Chinese with English abstract).

Zhang Z. C., Mahoney J. J., Mao J. W. and Wang F. S. (2006) Geochemistry of picritic and associated flows of the western Emeishan flood basalt province, China. J. Petrol. 47, 19972019.

Zhang Z. C., Mao J. W., Saunders A. D., Ai Y., Li Y. and Zhao L. (2009) Petrogenetic modeling of three mafic-ultramafic layered intrusions in the Emeishan large igneous province, SW China, based on isotopic and bulk chemical constraints. Lithos 113, 369-392.

Zheng Y. F., Zhao Z. F., Wu Y. B., Zhang S. B., Liu X. M. and $\mathrm{Wu}$ F. Y. (2006) Zircon U-Pb age, Hf and $\mathrm{O}$ isotope constraints on protolith origin of ultrahigh-pressure eclogite and gneiss in the Dabie orogen. Chem. Geol. 231, 135-158.

Zhong H., Hu R. Z., Wilson A. H. and Zhu W. G. (2005) Review of the link between the Hongge layered intrusion and Emeishan flood basalts, southwest China. Int. Geol. Rev. 47, 971-985.

Zhong H., Yao Y., Hu S. F., Zhou X. H., Liu B. G., Sun M., Zhou M. F. and Viljoen M. J. (2003) Trace-element and $\mathrm{Sr}-\mathrm{Nd}$ isotopic geochemistry of the PGE-bearing Hongge layered intrusion, southwestern China. Int. Geol. Rev. 45, 371-382. 
Zhong H., Yao Y., Prevec S. A., Wilson A. H., Viljoen M. J., Viljoen R. P., Liu B. G. and Luo Y. N. (2004) Trace-element and $\mathrm{Sr}-\mathrm{Nd}$ isotopic geochemistry of the PGE-bearing Xinjie layered intrusion in SW China. Chem. Geol. 203, 237-252.

Zhong H., Zhou X. H., Zhou M. F., Sun M. and Liu B. G. (2002) Platinum-group element geochemistry of the Hongge $\mathrm{Fe}-\mathrm{V}-\mathrm{Ti}$ deposit in the Pan-Xi area, southwestern China. Mineral. Deposita 37, 226-239.

Zhong H., Zhu W. G., Chu Z. Y., He D. F. and Song X. Y. (2007) SHRIMP U-Pb zircon geochronology, geochemistry, and Nd$\mathrm{Sr}$ isotopic study of contrasting granites in the Emeishan large igneous province, SW China. Chem. Geol. 236, 112-133.

Zhong H., Zhu W. G., Hu R. Z., Xie L. W., He D. F., Liu F. and Chu Z. Y. (2009) Zircon U-Pb age and $\mathrm{Sr}-\mathrm{Nd}-\mathrm{Hf}$ isotope geochemistry of the Panzhihua A-type syenitic intrusion in the Emeishan large igneous province, southwest China and implications for growth of juvenile crust. Lithos 110, 109-128.

Zhou B. F., Shi Z. M., Zhang Y. C. and Li X. (1985) A-type granites of the Panxi rift zone. In Corpus of the Panxi Paleorift Studies in China (ed. Y. X. Zhang). Geological Publishing House, pp. 201-223 (in Chinese with English abstract).

Zhou M. F., Arndt N. T., Malpas J., Wang C. Y. and Kennedy A. K. (2008) Two magma series and associated ore deposit types in the Permian Emeishan large igneous province, SW China. Lithos 103, 352-368.

Zhou M. F., Ma Y. X., Yan D. P., Xia X. P., Zhao J. H. and Sun M. (2006) The Yanbian terrane (southern Sichuan Province, SW China): a Neoproterozoic arc assemblage in the western margin of the Yangtze Block. Precamb. Res. 144, 19-38.

Zhou M. F., Malpas J., Song X. Y., Robinson P. T., Sun M., Kennedy A. K., Lesher C. M. and Keays R. R. (2002) A temporal link between the Emeishan large igneous province (SW China) and the end-Guadalupian mass extinction. Earth Planet. Sci. Lett. 196, 113-122.

Zhou M. F., Robinson P. T., Lesher C. M., Keays R. R., Zhang C. J. and Malpas J. (2005) Geochemistry, petrogenesis and metallogenesis of the Panzhihua gabbroic layered intrusion and associated $\mathrm{Fe}-\mathrm{Ti}-\mathrm{V}$ oxide deposits, Sichuan province, SW China. J. Petrol. 46, 2253-2280.

Zhu W. G., Zhong H., Deng H. L., Wilson A. H., Liu B. G., Li C. Y. and Qin Y. (2006) SHRIMP zircon U-Pb age, geochemistry and $\mathrm{Nd}-\mathrm{Sr}$ isotopes of the Gaojiacun mafic-ultramafic intrusive complex, SW China. Int. Geol. Rev. 48, 650-668.

Associate editor: Alan D. Brandon 